\title{
UNCLASSIIET
}

\section{FAST FLUX TEST FACILITY \\ CLOSED LOOP DEVELOPMENT \\ AND TESTING PROGRAM}

November 1968

\section{AEC RESEARCH \& \\ DEVELOPMENT REPORT}

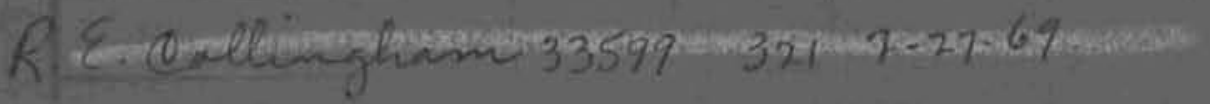

$\sin x$

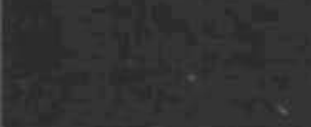


RERENT STITUS

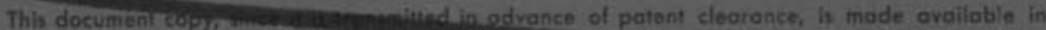

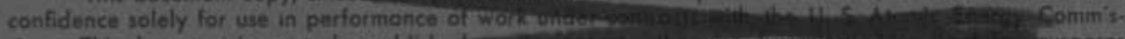

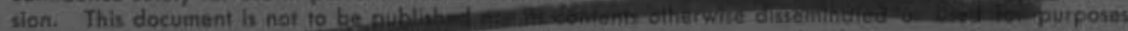

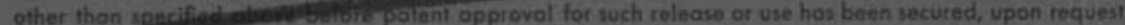
dinumane Enitu, Chicogo Patent Graup, U. S. Atomic Energy Commission. 9800 So, Coss Ave, Argonne IItinois.

\section{PREIIMINARY REPORT}

This report contains informotion of a preliminary nature prepared in the course of work under Atomic Eneroy Commission Contract AT(45-1).1830. This information is subject to correction or modifica fion upon the collection and evaluotion of odditional dato.

\section{LEGAL NO'TICE}

This report was prepared as an account of Government sponsoted wark. Neithet the United States nor the Commision, nor any person acting on behalf of the Commissions

A. Makes any warranty or representation, expressed or implied. with respectito the accuracy, coms pleteness, or usefulness of the intormation contained in this report. or that the use of any imformation, opparatus method, or process disclosed in this report may not infringe privately owned rights: os

B. Assumes any liabilities with respect to the use of of for damoges resulting from the use of ony information, apporatus, method, or process disclosed in this report.

As used in the above, "perion octing on behalf of the Commission" includes any employee or contractor of the Commission, or employve of such contractor. O the extent that such employee of con troctor of the Commistios, or employee of such contector prepares disseminates, or provides access to any informatian pursuont to his emplayment or contract with the Commission, or his employment with such contractor.

PACIFIC NORTHWEST LABORATORY RICHLAND, WASHINGTON operafed by BATTELLE MEMORIAL INSTITUTE

for the UNITED STATES ATOMIC ENERGY COMMISSION UNDER CONTRACT AT(45-1)-1830 

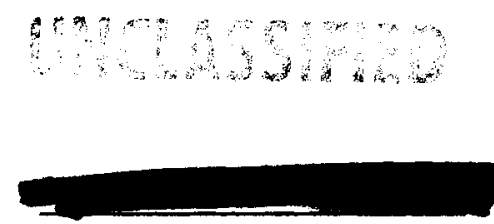

BNWL -852

33679000611469

\section{FAST FLUX TEST FACILITY \\ CLOSED LOOP DEVELOPMENT \\ AND TESTING PROGRAM}

By

R. Kolowith

Approved by

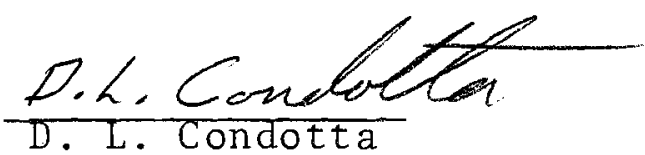

November 1968

BATTELLE MEMORIAL INSTITUTE

PACIFIC NORTHWEST LABORATORY

RI CHLAND, WASHINGTON 
Hat. . . . . .

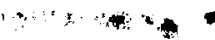




\section{TABLE OF CONTENTS}

INTRODUCTION

PURPOSE • •

SUMMARY AND CONCLUSIONS

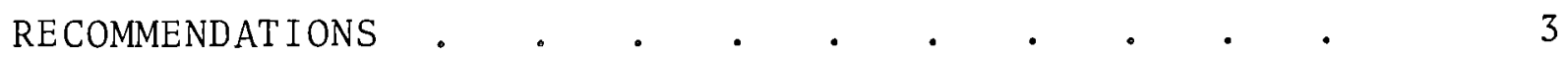

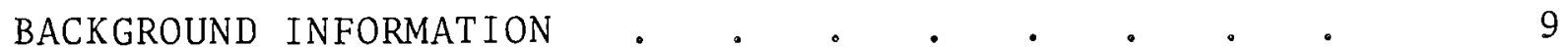

PROPOSED CLOSED LOOP SYSTEM TEST PROGRAM . • • . 10

CLOSED LOOP SYSTEM COMPONENTS. • • • • • • 12

Closed Loop Tubes . . . . . . . . 12

Nozzle and Spool Piece. . . . . . . 14

Primary and Secondary Pumps . . . . . . 15

Interconnecting Piping . . . . . . . . . 17

Intermediate Heat Exchangers. . . . . . 18

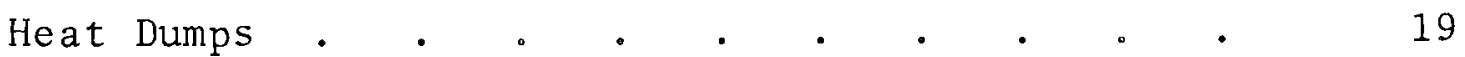

JUSTIFICATIONS FOR CLOSED LOOP SYSTEM TESTING. • 。 20

Transients . . . . . . . . . . . 20

Thermal Stresses. . . . . . . . . 22

Insulation . . . . . . . . . . . 24

Vibration .

Accident Analysis . . . . . . . . 26

Remote Maintenance . . . . . . . . 29

Fuel Handling and Tube Replacement . 。 . . 30

Instrumentation and Contro1 . . . . . . 31

Thermal Hydraulics . . . . . . . 33

Nonradioactive Isotope Transport. . . . . 34

Mechanical Fit . . . . . . . . . 35

Coolant Purity Considerations . . . . . . 36

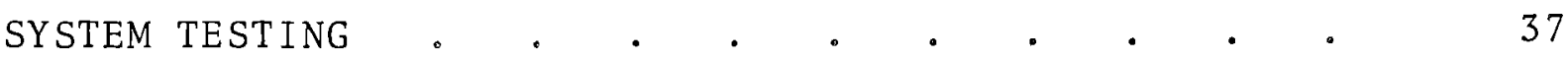

Operating Procedures. . . . . . . . . 38

Unforeseen Problems 。 • • • • • . . 39

Maintenance. . . . . . . . . . 40

Operating Experience. . . . . . . . 40

Quality Assurance . . . . . . . . 41 
SYSTEM TEST ENVIRONMENTAL REQUIREMENTS . • . • • 41 CONCEPTUAL TEST PLAN AND SCHEDULE . • . . . . 43

Preoperational Testing . . . . . . . . . . . 43

Steady-State Testing . . . . . . . . . . . . . 46

Transient Testing . . . . . . . . . . . 47

Remote Operations Testing . . . . . . 47

Accelerated Life Testing . . . . . . . . . 48

Decontamination Testing . . . . . . . . . . 48

ALTERNATE SYSTEM TEST CONCEPTS . . . . . . . 49

Alternate I . . . . . . . . . . . . 49

Alternate II $. \quad . \quad . \quad . \quad . \quad . \quad .54$

Alternate III . $\quad . \quad$. $\quad . \quad . \quad 056$

Alternate IV . . . . . . . . . 58

Alternate $\mathrm{V}$. $. \quad . \quad . \quad . \quad . \quad . \quad . \quad . \quad 060$

Alternate VI . . . . . . . . . . . 60

ALTERNATE SYSTEM TEST LOCATIONS AND SCHEDULES • • . 63

Locations . . . . . . . . . . . . 63

Schedules . . . . . . . . . . . . . 63

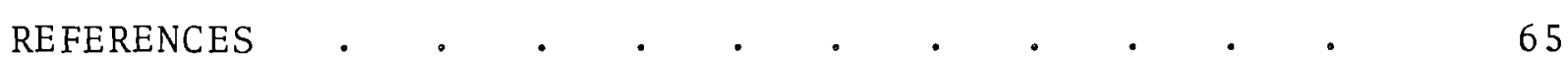




\section{LIST OF FIGURES}

1 Conceptual Closed Loop System Test Schedule

2 Proposed Closed Loop Prototype Test Installation - Alternate IB

3 Proposed Closed Loop Prototype Test Installation - Alternate IIB

4 Proposed Closed Loop Prototype Test Installation - Alternate IIIB

5 Proposed Closed Loop Prototype Test Installation - Alternate IVB

6 Proposed Closed Loop Prototype Test Installation - Alternate VB

7 Proposed Closed Loop Prototype Test Installation - Alternate VIB

8 Installation Acquisition Schedule for Alternate III 


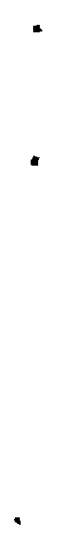

.<smiles>C1CC1</smiles>

- 


\section{FAST FLUX TEST FACILITY \\ CLOSED LOOP DEVELOPMENT \\ AND TESTING PROGRAM}

R. Kolowith

\section{INTRODUCTION}

The primary objective of the Fast Flux Test Facility is to provide reliable closed loop testing, making the FFTF closed 1oop systems one of the principal research tools of the Liquid Metal Fast Breeder Reactor program. (1) In support of this objective, the availability of the Fast Test Reactor (FTR) is to be as high as practically attainable. Therefore, the demonstrated availability of the closed loops must be correspondingly high. However, the severity of high neutron flux combined with high operating temperatures for extended periods of time will press the limits of current materials technology and make the attainment of a reliable closed loop system difficult. In addition, the nature of the tubed reactor configuration may tend to cause structural dynamic fatiguing, and accident-induced temperature and pressure transients can impose severe operating stresses on closed loop components. It is also anticipated that future closed loops installed in the FFTF may reflect significant departures in design. Without a closed loop development and testing program established ahead of time, the primary objective of the FFTF will be jeopardized.

\section{PURPOSE}

The objectives of this report are to:

- Justify the development and acquisition of an experimental installation for proof testing of closed loop components and systems of the FFTF. 
- Recommend the scope of an experimental Closed Loop System Test Installation (CLSTI).

- Present a tentative program for development and testing of the closed loop system.

\section{SUMMARY AND CONCLUSIONS}

In support of the development and acquisition of a Closed Loop System Test Installation for FFTF, the following closed loop test applications are examined:

- Verification of analytical design.

- Investigation of FTR performance parameters and limited transient effects.

- Demonstration of remote handling and maintenance equipment.

- Testing of closed loop system components.

- Training of operators and maintenance personnel.

The study concludes that an experimental closed loop system test program is required to assure success of the FFTF closed loops. The objectives of such a program can be met by an installation providing a reasonably full simulation of the anticipated environment without necessitating neutron flux simulation.

An idealized list of closed loop system test environmental requirements is shown in Table II later in this report. The degree of fulfilling these requirements by each of six alternate test installation concepts is also given. The alternates are evaluated and one is recommended. A conceptual test program developed for the recommended installation features the following phases of testing:

1. Preoperational Testing

2. Steady-State Testing

3. Transient Testing 
BNWL -852

4. Remote Maintenance Testing
5. Accelerated Life Testing
6. Decontamination Testing.

A three-year schedule of time required to complete such a test program is shown in Figure 1 .

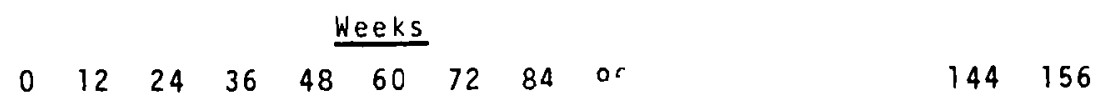

Preoperational Testing

Steady-state

Testing

Transient

Testing

Remcte Mainte-

nance Testing

Accelerated

Life Testing

Decontamiriation

Testing

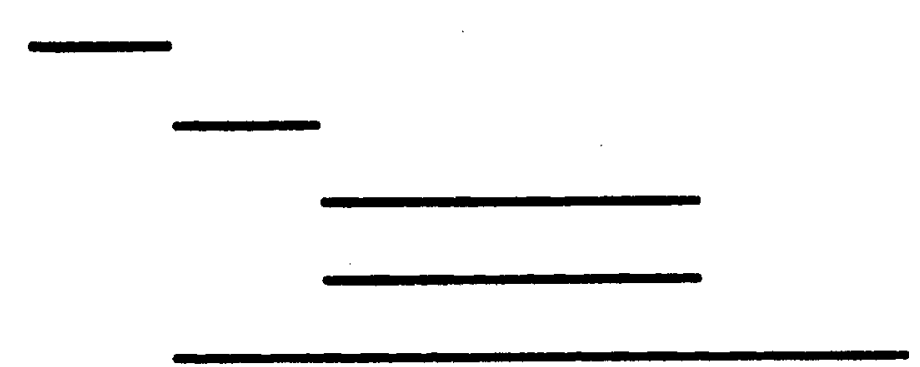

FIGURE 1. Conceptual Closed Loop

System Test Scheduze

\section{RECOMMENDATIONS}

A summary of key system features and estimated construction costs is given in Table I for each of six alternate Closed Loop System Test Installation concepts which were considered.

Neutron flux simulation is not considered feasible from schedule and cost considerations for a closed loop system test, and is not proposed for any of the six test concepts. The flux level in the FFTF neutron environment will be higher than any existing reactor so that the time required to achieve a similar exposure would be prohibitive. 


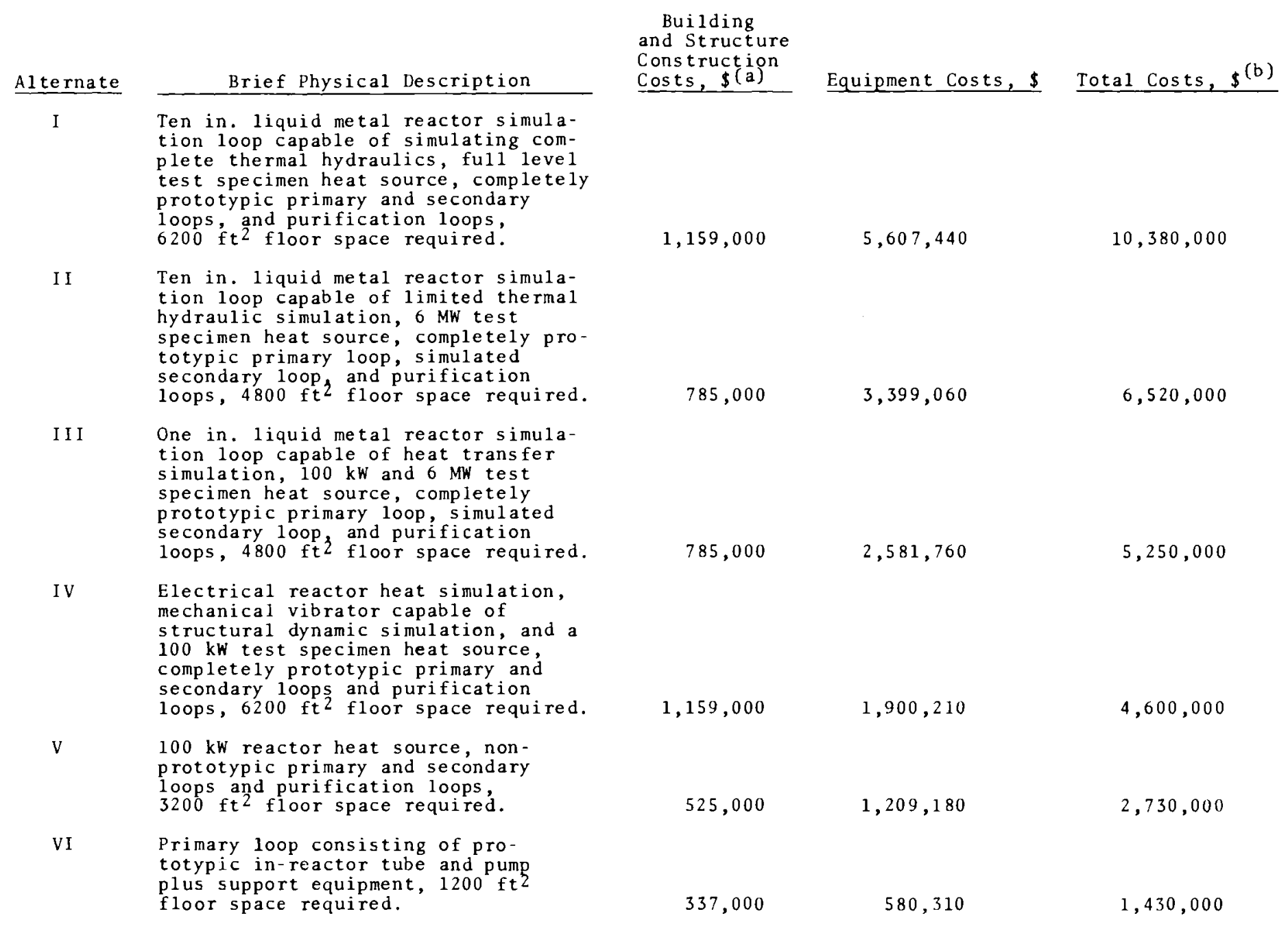

(a) These costs are representative of a new building constructed only for closed loop system testing (including engineering). The costs are presented for comparison only and are not the approach being pursued.

(b) Including $25 \%$ contigencies, $10 \%$ escalation, and $20 \%$ engineering. 
Materials irradiation data exist for a fluence only of $10^{22}$ nvt. A primary purpose of the FFTF is to investigate irradiation effects beyond the existing data. Even if neutron flux simulation were feasible for the closed loop system test, the absence of radiation is desirable because of the increased freedom given to test personnel for routine test activities.

It is not possible to construct a $6 \mathrm{MW}$ nonnuclear heat source with the same size as the anticipated closed loop test specimen. Indeed it appears that a $100 \mathrm{~kW}$ heat source is the largest which may be constructed within the space restrictions of the test specimen. Therefore, for the closed loop system testing it is necessary to give up either the prototypic location of the heat source or the prototypic capacity of the heat source. It is recommended that prototypic location be maintained. This will allow a simulation of radial $\Delta T$ for the closed loop tube thermal stress analysis.

From the standpoint of out-of-reactor closed loop thermal stress simulation, it is not advisable to give up prototypical capacity. Alternate concepts I, II, and III provide a $6 \mathrm{MW}$ out-of-reactor heater capable of full out-of-reactor thermal simulation.

It is not economically practical to simulate a reactor vessel vertical pressure profile that is completely prototypical. It is possible, by proper orificing, to simulate the reactor vertical total $\triangle \mathrm{P}$. However, it is neither economically justifiable nor necessary from a technical viewpoint to simulate the total $\Delta \mathrm{P}$ at predicted operating inlet pressures. Extreme reactor pressure and temperature transient simulation capabilities associated with a Design Basis Accident (DBA) are not within the scope of the proposed Closed Loop System Test Installation. Any experimental demonstration of these parameters required to meet code and nuclear safeguards requirements must be performed at the Transient Reactor Test Facility (TREAT). 
These transients cannot be performed in the proposed test installation because of the lack of technology and the added expense necessary to comply with personnel safety requirements.

The reactor vessel thermal hydraulic simulation provided by the alternate concepts is designed to cover the entire range, from a full simulation to no simulation at all.

Alternate I provides a simulated reactor vessel with sodium flow around the closed loop tube at prototypical rates and temperature profiles. The total flow considered consists of a vertical leakage flow component and a horizontal crossflow component (from adjacent driver ducts). To simulate this flow requires a 10 in., 2000 gpm sodium system. A 30 MW heat source is required to maintain a prototypical reactor vessel vertical $\Delta \mathrm{T}$ at simulated full flow. Both prototypical flow and temperature are desirable from the standpoint of structural dynamic experimentation.

Alternate II provides the same prototypical reactor vessel flow around the closed loop tube with a reduced capacity heat source. This arrangement provides the capability to subject the closed loop system either to prototypical reactor vesse1 flow at a reduced $\Delta \mathrm{T}$ or to prototypical reactor vessel $\Delta \mathrm{T}$ at reduced flow. An inherent disadvantage of this concept is the inability to generate prototypical reactor vessel flows around the closed loop tube at the correct temperature profile. Structural dynamic experimentation under these conditions can lead to erroneous results.

Alternate II provides a reactor vessel with flowing sodium simulation at both reduced flow and consequently reduced heat capacity. This concept provides a prototypical reactor vessel vertical $\Delta \mathrm{T}$ at reduced flow. Cumulative thermal stress experiments could be performed with this concept, while structural dynamic effects would be studied in the full scale Hydraulic Core Mockup (HCM). The HCM does not provide flows at prototypical temperature conditions. 
Alternates IV, V, and VI provide no thermal hydraulic simulation of the reactor vessel sodium system. This approach necessitates a certain amount of risk in providing assurance of the structural integrity of the closed loop system, and the closed loop in-reactor tube, in particular. Alternate IV does provide an electrodynamic mechanical shaker to permit investigation of structural characteristics of the closed loop system. This investigation could be in the form of predicted envelope tests prior to reactor startup, in the form of dynamic duplication of the FTR environment concurrent with FTR operation, or a combination of both.

The fuel handling machine interfaces with the handling of the closed loop tube, test specimens, and instruments are within the scope of all six alternate concepts and may be experimentally demonstrated in the proposed Closed Loop System Test Installation. Both sides of these interfaces are complex systems. Therefore, considering the proposed test installation operating schedule and the broader scope of the Fuel Handling Machine (FHM), it is currently believed that it may be desirable to check out the FHM over both the closed loop system and the Reactor Cover Mockup, or entirely over the Reactor Cover Mockup. Consequently, the equipment costs for the fuel handling machine are not included in the equipment costs of Table I.

The ideal test installation, disregarding costs and schedules, would be a duplicate FTR. If costs alone were of no concern, the most complete simulation possible, short of neutron flux simulation, would be desirable. Alternate $I$ is an example of such an installation (costing about $\$ 10,380,000$ ). However, for reasons that follow, it is felt that the objectives of the closed loop development program can be met with a limited installation such as Alternate III $(\$ 5,250,000)$. 
Therefore, it is recommended that the proposed concept designated Alternate II be built and used to system test a closed loop. Briefly, the concept consists of a structure, a reactor simulation liquid metal loop, a complete primary closed loop, a simulated secondary closed loop, and auxiliary sodium purification systems. The test installation will be capable of simulating all anticipated closed loop environments except nuclear heating, neutron flux, and complete reactor hydraulics. The test installation loops provide the features necessary to investigate out-of-reactor thermal stresses, thermal ratcheting, remote decontamination, remote maintenance, mechanical and hydraulic vibrations induced by the closed loop system, limited hydraulic vibrations induced by the reactor simulation, gas entrainment, mass transport, system and subsystem pressure drops, heat exchanger heat transfer coefficients, stratification of coolant on all the components and piping, sodium purification technology, and automatic and manual process control.

Alternate III is recommended, instead of Alternates $I$ and I , to avoid the greater cost associated with a complete thermal hydraulics simulation. Study has indicated that the added cost required to achieve full reactor simulation cannot be justified by the small increase in the level of confidence of the data acquired. Therefore, it is recommended that the hydraulics testing of the closed loop tube be performed on the full-scale Hydraulic Core Mockup. This approach is consistent with the plans for testing the driver fuel ducts. Another basis of selection is the need for full-scale reactor heating to adequately evaluate the thermal hydraulic characteristics of the intermediate heat exchanger and the entire secondary 1 oop.

Alternate IV is not capable of permitting investigation of the thermal environment, one of the severest parameters predicted for the closed loop systems. This alternate, with no 
BNWL -852

large heat source simulation, is capable of only isothermal steady-state operation. No transient or thermal cycle endurance testing could be performed with this alternate. In addition, the steady-state testing would be very limited.

Alternate $V$ affords essentially isothermal steady-state hydraulic, remote maintenance, and decontamination experimentation of a limited system.

Alternate VI affords only isothermal steady-state hydraulic, remote maintenance, and decontamination testing of a limited primary loop.

Unfortunately, none of the last three alternates investigate the parameters most likely to propagate hazardous failures. There is little question that the in-reactor tube will see the most severe environment. Therefore, it is fundamental from a technical and reliability standpoint that this piece of hardware be given the most attention. One can rationalize that the in-reactor tube can be most economically verified by testing it as a component. However, in considering all factors such as cost, avajlability, and degree of test confidence, it appears that the in-reactor tube can best be verified in a closed loop system test installation. Therefore, it is essential that the test installation have some reactor simulation capabilities. It is believed that the combination of the Closed Loop System Test Installation Alternate III and the fullscale HCM can permit adequate evaluation of the closed loop system with the exception of the in-reactor tube. It is anticipated that a minimum amount of testing in the reactor during early operation is required to provide full range testing including the neutron environment.

\section{BACKGROUND INFORMATION}

Activity in closed loop testing for liquid metal systems extends back into the late fifties. TID-8505, Report on Civilian Reactor Fuel Elements, June 1959, contains a brief survey 
of the test facilities existing then. At that time the re were no facilities other than EBR-I for irradiation of fuel materials in a fast flux. Irradiations in EBR-I would have required replacing standard fuel assemblies with experimental assemblies of identical shape and dimensions. Other disadvantages to this approach were low flux levels and small core size. Fuel element test loops containing the coolant of interest were proposed as one alternative.

Since this initial effort, liquid metal loops have appeared at the ATR, BR-2, CABRI, CP-5, ETR, EBR-II, Fermi, LAMPRI-I, MTR, LITR, PEC, TR-SRE, and TREAT reactors. (2) The degree of development undertaken for each of the systems has varied greatly. The facilities required for this development varied from use of the reactor itself, to water mockups, to complete prototypes.

The general philosophy of systems testing is expressed by a group of French authors (3) in connection with their Rapsodie reactor. They essentially "built their reactor twice" by conducting system tests on virtually all components. Among the systems employed was a $10 \mathrm{MW}$ loop that tested pumps, heat exchangers, and other pertinent apparatus. They felt that the efforts were well worthwhile from several standpoints, including:

- Proof of components in combination.

- Training of personnel, both technical and operations.

- Solution of detailed technical problems at less cost in time and labor than by solving them on the reactor itse $1 \mathrm{f}$.

\section{PROPOSED CLOSED LOOP SYSTEM TEST PROGRAM}

The testing philosophy and associated broad experimental installation requirements for development of the FFTF reactor assembly have been previously identified and described. 
Using these requirements and the results of a literature search and undocumented personal experiences, a more specific development and testing program for a closed loop system is presented in this report. The program consists of tube and hardware development, out-of-reactor loop component development, installation preparation, and finally, actual system testing of the closed loop. Closed loop components such as closures, seals, pumps, heat exchangers, and valves are to be individually tested in appropriate environments for proof-of-principle and design verification. In general, component concepts with proven performance capabilities closely approximating the needs of the closed loops will be selected. Where modifications are indicated, design studies will be conducted to provide guidance for the modifications and to close the technology gap where it exists. Many of the minor components are expected to be so well within the state-of-technology that only procurement and confirmation testing of representative samples will be required.

Detail designs and fabrication specifications will be prepared for prototypes, subassemblies, and models as required, and these items will be subjected to development testing either in the system test installation or offsite, depending upon the thermal shock and heat transfer capabilities of the proposed installation.

Although pumps for closed loop service are within proven sodium technology for capacity and temperature, some extrapolations from the current knowledge will be necessary to achieve the required total dynamic head, shaft lengths, and seal and bearing designs.

Intermediate and dump heat exchangers have been designed and built for service conditions closely approximating the requirements of the closed loops. Although operating experience with these heat exchangers has not been extensive, no large technological gap appears to exist. 
The closed loop in-reactor tube will be pressure and temperature transient tested as an individual component prior to installation into the test installation. These preinstallation tests are desirable from the standpoint of reduced facility cost and increased facility availability for system activities. Demonstration of individual component compatibility and operability, when integrated into a complete system, requires a closed loop system test.

When construction starts on the closed loop system test installation, the design details of the FFTF closed loop system will not be completed. Therefore, the test installation must be sufficiently flexible to accept some loop design variation. Potential problems and requirements in connection with the ongoing research program, after commissioning of the FFTF, must be appropriately considered in closed loop development planning

The potential problems in the FFTF closed loop system after component development and design verification testing can be classified as (1) component endurance, reliability, and interface coordination, (2) system performance, and (3) long term operational needs.

\section{CLOSED LOOP SYSTEM COMPONENTS}

The principal closed loop system components are the closed loop tubes, nozzle and spool pieces, primary and secondary pumps, interconnecting piping, intermediate heat exchangers, and the air blast heat dumps. These components are described with consideration given to their current state-of-technology and probable extension to FFTF performance requirements. Potential problem areas are highlighted, and the need for, and benefits of, a closed loop system test installation are summarized.

\section{CLOSED LOOP TUBES}

The purpose of the closed loop tubes is to accurately maintain the position of test specimens in the FTR and provide 
ducting for sodium at localized temperatures to $1400^{\circ} \mathrm{F}$. The tubes will also provide insulation of the loop system sodium from the reactor primary sodium for temperature differences up to $400^{\circ} \mathrm{F}$. The closed loop hot leg must be designed to operate ultimately at $1200^{\circ} \mathrm{F}$.

The major potential problems associated with the closed loop tubes involve reactivity effects and structural integrity. Both are related to tube movement, distortion, or failure. The tube-fuel position, and thus reactivity, can be affected by such factors as thermal stress, thermal expansion, loads and moments imposed by the reactor structure and mechanical and flow-induced vibrations. Coolant channeling in the fue 1 duct can result from tube distortion caused by creep and thermal bowing. Failure of the tube can result from a combination of creep, thermal ratcheting, and cyclic mechanical and thermal stresses. Insufficient experience with fast reactor tube performance and severity of operating conditions compel design verification, endurance, and reliability testing of the closed loop tubes prior to commitment to the FTR.

Initial proof and design verification testing will subject the tube to prototypical conditions of pressure and temperature at the TREAT similar facility. Flow testing using water will be performed in the Hydraulic Core Mockup. (4) Tube distortion, vibrational stress, and mechanical fit problems will be evaluated by direct dimensional measurements, photoelastic coatings, strain gages, vibration sensing, and noise sensing equipment.

Closed loop system testing is needed for further evaluation of in-reactor tube performance. Vibration or movement characteristics of the tube, when in exact mechanical relationship to the closed loop system, should be determined. Distortions of the tube as a structural member of the reactor 
under simulated operation should be determined. Neutronic specimen damage, mechanical operations to replace tests, creep, thermal ratcheting, and yielding are potential causes of distortion.

Evaluation of thermal insulation under the worst expected condition of reactor and closed loop system operation should also be simulated in the systems test. In particular, the possible dual necessity of insulating the closed loop channels from the reactor during normal operation, and utilizing the reactor as a closed loop heat sink during emergency conditions should be evaluated. Potential methods of accomplishing this apparently self-contradictory requirement include using sintered stainless steel between the tube walls, flooding the gas gap, and making use of different gases to control the conductivity under the emergency conditions. All methods require experimental verification to ensure reliability.

\section{NOZZLE AND SPOOL PIECE}

The apparent major potential problems associated with the nozzle and spool piece involve prevention of sodium leakage at joints and seals, and avoidance of serious structural damage from sustained and cyclic mechanical and thermal stresses. Creep, fatigue, gross thermal distortion, and possibly thermal ratcheting can result from sustained and cyclic temperatures and pressures existing between inlet and outlet sodium, and from system thermal, mechanical, and hydraulic shock.

Component proof-of-principle verification, reliability, and design verification testing will involve subjecting seals to prototypical conditions. In particular, mechanical, hydraulic and thermal coupling with the system, which could not be simulated feasibly on a given component during static testing, should be provided during closed loop system testing. 
The closed loop systems test should provide for evaluation of the nozzle and spool piece in the following areas:

- Adequacy of seals under operating conditions including system temperatures and loads.

- The degree of thermal stresses and thermal strains for the specific hardware geometry under system operating conditions. It is not possible to accurately determine the magnitude of thermal stresses because thermal strains, by tending to concentrate in regions of highest temperatures, produce a highly localized large strain. Thermal distortion is highly dependent upon the geometry of the spool piece and the degree of system restraint.

- The occurrence of thermal fatigue resulting from temperature variations or of mechanical fatigue from pressure loads and vibrations.

- The presence of mechanical and hydraulic vibrations between the nozzle-spool piece and the interconnecting piping for systems operation.

\section{PRIMARY AND SECONDARY PUMPS}

The reference concept for both the primary and secondary closed loop pumps is a free-surface, vertical, multi-stage centrifugal pump with ac squirrel cage motors and eddy current couplings. Units of this type, represented by the Los Alamos Scientific Laboratory (LASL) and Fermi overflow pumps, are the most successfully proven of all sodium pumps, having logged as many as $44,000 \mathrm{hr}$ of operation without serious difficulties. Multi-stage centrifugal designs require no barrel and may be installed directly into surge tanks, resulting in reductions of system complexity and overall costs.

While no existing sodium pump adequately covers all the requirements of the FFTF closed loop pumps with the possible exception of the Rapsodie primary pump (a single stage unit), 
all parameters are covered in various types of designs. The Rapsodie primary pump meets closed loop secondary system performance requirements adequately and is a proven design of the Fermi type. Multi-stage types such as the LASL and Fermi overflow pumps are preferable from the standpoint of cost, simplicity, and compactness. For these units, only minor departure would be required from existing state-of-technology in the area of pump capacity。

The referenced primary closed loop pumps have parameters similar to the CANEL pumps with the exception that the CANEL pumps are canned-rotor, oil-filled motor types. A choice exists in converting the CANEL designs to vertical free surface, or in extrapolating the Fermi overflow pumps to $600 \mathrm{ft}$ TDH. The preferred concept, ${ }^{(5)}$ the well proven Fermi overflow multi-stage, free-surface pump, would represent lower cost, greater simplicity, and greater compactness.

While helical rotor and electromagnetic (E.M.) pumps may be parametrically extended for FFTF closed loop pumps, the extensions from existing state-of-technology present major problems in size, costs, weight, availability and reliability. The state-of-technology in this type of unit is very weak, and much development work is required to correct the causes of the consistent failures still being experienced. The extrapolation to a $600 \mathrm{ft}$ TDH with the thin duct wall is the most serious problem to overcome. Duct wall failures in pumps of this kind are most common, even at low $\mathrm{TDH}$. The helical rotor pumps do have some advantages which may eventually justify back-up designs for long-term test evaluation in the prototype closed 10op. A closed 10op E.M. primary pump is estimated to weigh between 5 and 7 tons. Excessive construction costs would be expected in housing pumps of this size and weight. 


\section{INTERCONNECTING PIPING}

Safety and continuity are the principal concerns in the design and performance of the sodium piping in a loop system. The reference design embodies single-walled piping for the primary and secondary closed loops. A study was made ${ }^{(6)}$ of the need for double containment in the primary and secondary loop piping of the FFTF closed loops. Conclusions of the study were that justification for the added expense and difficulties of providing double contained piping would hinge primarily on the probability of a major or minor pipe failure in the primary system. Failure could arise from such causes as one or more of the following:

- Excessive stresses

- Vibration (fatigue)

- Propagation of defects

- Corrosion

- Thermal effects.

Failures in the secondary loop piping, while not normally of serious consequence, could lead to damage of other loop components, and to disabling fires.

Estimates of the effects of these and other parameters on the probability of piping failure can only be based on calculations and on experience with systems operated under less rigorous conditions. The proposed closed loop system test would allow proof of these estimates under conditions equaling or surpassing in severity those expected during reactor operation. Tests would be made on a non radioactive system eliminating the factor of contamination from those tests run to destruction.

Piping systems of this type were built at Argonne National Laboratory to test a section of the core of EBR-II 
(1957) and the proposed FARET (7) reactor (1965). These systems were built to test many parameters. Among them were measurements of actual stresses in piping components and a comparison with analytic figures. A complete system was built for each of the two reactors because the first was to operate at $900{ }^{\circ} \mathrm{F}$ and the second at $1200^{\circ} \mathrm{F}$. The FARET loop (now called Core Components Test Loops or CCTL) is now used for some phases of FFTF testing but only within its temperature limitation of $1200{ }^{\circ} \mathrm{F}$ (FFTF closed loops are to go to $1400^{\circ} \mathrm{F}$ ) and pressure limitation of $150 \mathrm{psi}$.

INTERMEDIATE HEAT EXCHANGERS

Intermediate heat exchangers for the closed loops will be designed for duty ratings of approximately $6 \mathrm{MW}_{t}$ and for the capability of operating with primary sodium at temperatures up to $1200^{\circ} \mathrm{F}$. The physical size and process service conditions for these units are not significant extrapolations from the several existing Intermediate Heat Exchanger (IHX) designs. Heat exchangers typifying the FFTF closed loop requirements include:

\begin{tabular}{|c|c|c|c|}
\hline Facility & Manufacturer & $\begin{array}{l}\text { Design } \\
\text { Rating, } \\
\quad M W_{t} \\
\end{array}$ & $\begin{array}{c}\text { Structural } \\
\text { Design } \\
\text { Temperature, } \\
{ }^{\circ} \mathrm{F} \\
\end{array}$ \\
\hline SCTI (test unit) & ALCO & 30 & 1200 \\
\hline $\mathrm{SRE}-\mathrm{PEP} *$ & $\mathrm{ALCO}$ & 45 & 1200 \\
\hline Rapsodie (French) & Stein and Roubaix & 10 & $>1000$ \\
\hline $\operatorname{SEFOR}(\operatorname{main}) *$ & $\mathrm{BLH}$ & 20 & 1050 \\
\hline SEFOR (auxiliary)* & B LH & 2.5 & 1050 \\
\hline $\begin{array}{l}\text { LASL (test } \\
\text { prototype) }\end{array}$ & LASL & 2 & 1200 \\
\hline LASL (FRCTF)* & $\mathrm{BLH}$ & 5 & 1200 \\
\hline Hallam & M. W. Ke $1 \log$ & 42 & 1000 \\
\hline INTERATOM (Ge rman) & Babcock \& Wilcox & 5 & $\therefore 1040$ \\
\hline
\end{tabular}

* IHXs have not been subjected to operational testing to date. 
Development of the closed loop IHXs will rely heavily upon technology proven through design, fabrication, and operation of existing equipment; and unnecessary design inovations will be avoided. Although a reasonably adequate technological background exists, none of the proven IHXs represent an "off the shelf" design directly adaptable to the closed loop requirements. As a minimum, some modification to physical size and configuration of existing units will be necessary. Verification proof testing of a prototype IHX (preferably full scale) is recommended to ensure satisfactory attainment of the rmal performance, structural reliability, and maintainability.

\section{HEAT DUMPS}

Heat from the closed loop sodium systems is dissipated to ambient air by air blast heat dumps. Each heat dump will be designed for a nominal duty rating of $6 \mathrm{MW}_{t}$ and a capability for achieving design rating throughout an inlet sodium temperature range from 700 to $1100^{\circ} \mathrm{F}$. Structural design temperature for sodium pressure parts is $1200^{\circ} \mathrm{F}$.

A number of sodium-to-air heat exchangers of approximate size and general design characteristics comparable to the FFTF closed loop requirements have been designed, fabricated and, in most instances, satisfactorily operated. Existing heat dump installations offering promise of contributing proven technology for the FFTF design conditions include:

\begin{tabular}{|c|c|c|c|}
\hline Facility & Manufacturer & $\begin{array}{l}\text { Design } \\
\text { Duty } \\
\text { Rating, } \\
\text { MWt } \\
\end{array}$ & $\begin{array}{c}\text { Structural } \\
\text { Design } \\
\text { Temperature, } \\
{ }_{\mathrm{F}} \\
\end{array}$ \\
\hline SCT I & $\begin{array}{l}\text { Baldwin Lima } \\
\text { Hamilton }\end{array}$ & 8.5 & 1320 \\
\hline SRE (main) & ALCO Products & 20 & 1200 \\
\hline SRE (auxiliary) & ALCO Products & 1 & 1200 \\
\hline $\operatorname{SEFOR}$ (main)* & $\begin{array}{l}\text { Baldwin Lima } \\
\text { Hamilton }\end{array}$ & 20 & 1000 \\
\hline
\end{tabular}

* Has not been placed in operation. 


$\frac{\text { Facility }}{\text { SEFOR (auxiliary)* }}$
MSA
LASL (LAMPRE-I)
LASL (FRCTF)*
Pratt \& Whitney
Cadarache (France)

Manufacturer
Baldwin Lima
Hamilton
Griscom Russe 11
Griscom Russe 11
Struthers We $11 \mathrm{~s}$
Griscom Russe 11

Manufacturer

Baldwin Lima

Hamilton

Design

Duty

Rating,

$\mathrm{MW}_{\mathrm{t}}$

2.5

3

2

5

8

10
Structural

Design

Temperature, ${ }^{\circ} \mathrm{F}$

1000

(No Data)

1200

1200

1500

(No Data)

* Has not been placed in operation.

As in the case of the intermediate heat exchangers, it is unlikely that any single one of the proven heat dump designs will directly satisfy all FFTF closed loop design conditions. Hence, the FFTF design must be synthesized by using a composite of proven design features. Despite a reasonably well-established technology, this design approach involves some risk and should be backed by a final verification proof-testing program to ensure satisfactory thermal and mechanical performance, stability of cooling load control, and structural reliability.

\section{JUSTIFICATIONS FOR CLOSED LOOP SYSTEM TESTING}

Individual components comprising the FFTF closed loop systems are expected to be developed by both proof-of-principle and design verification testing. However, assurance of success in a timely manner for the FFTF program requires that the aggregate of components be tested as systems to evaluate and possibly resolve a variety of potential problems. These problems are discussed in the following paragraphs.

\section{TRANSIENTS}

Development of operating procedures and limits will require a complete analysis of the response of the closed loop complex 
to various transient effects possibly associated with normal operations, or caused by equipment malfunction or operator error. Many of these transients are associated with accident analysis and, therefore, are discussed in the section entitled "Accident Analyses." This discussion is limited to transients expected to result from normal operations or noncatostrophic equipment failure. Generally, these transients profoundly affect operating limits of power, temperature, and pressure for a nuclear system.

Although most of these transients can be calculated, system kinetic characteristics such as mechanical friction, fluid friction, feedback effects, interface effects, and control circuit frequency response can only be estimated. Although use of conservative estimates is generally expected to cause no difficulty, the effects of these transients must be thoroughly explored to insure that the following performance criteria are met:

- The system shall be designed such that a single closed loop pump failure will not require reactor shutdown.

- Programmed reactor power level changes shall not cause thermal transients or fuel gas pressure transients sufficient to cause stress failure of fuel elements or of coolant system components.

- Changes in reactor power level, thermal transients, or flow transients shall not cause in-reactor test specimen shifts which could result in positive reactor reactivity changes .

While these transient aspects of closed loop operation cannot be completely explored by use of a closed loop system test, sufficient experimental work can be performed to support appropriate assumptions by extrapolation. More significantly, endurance data acquired during all phases of the closed loop system experimental program (steady-state and transient) will be of great value in identifying problem areas for appropriate corrective action. 


\section{THERMAL STRESSES}

Investigation of thermal stresses in the FFTF closed 1oop system will require a rigorous program of stress analysis and experimental verification of design to ensure component and system reliability. Because of the high heat transfer rate of liquid sodium, large temperature differences will be developed in the system components. Austenitic stainless steels can develop higher thermal stresses than most structural metals because of their low thermal conductivity and high coefficient of expansion. Also, problem areas can be anticipated because of the use of austenitic stainless steel in most of the sodium system.

Calculations can be performed to predict the thermal expansion and the resulting stresses and deflections of the piping and associated components of the integrated system. However, calculations for many regions, such as nozzles and hot and cold stream mixing areas, are extremely difficult and require testing for verification. The Liquid-Metals Handbook advises that in cases where the thermal stresses are in the plastic range, full-scale models should be used if possible, and experimentally analyzed under realistic conditions simulate actual service.( 8$)$

In regions where a hot and cold stream mix, as at the tee connection of a bypass stream, the mixing action cannot be predicted, nor can the stress distribution be determined analy. tically. Such a case occurred on the Fuel Element Rupture Test Facility (FERTF), a pressurized, light water closed loop in the PRTR at Hanford. Thermal stresses were not predictable at the junction of the coolant effluent and a bypass stream. The design adequacy was verified prior to reactor startup by instrumenting the problem area and subjecting the loop to simulated normal and transient conditions such as power 1 oss and 
reactor scram. In another example, discussed in Component Failure Modes and Mechanisms as Applied to Nuclear Power P1ants, (9) failure occurred in 304 SS piping from thermal fatigue as the result of colder water introduced into a hot stream。

Experimental verification of designs for similar FFTF closed loop situations should be done in a closed loop system test to avoid the possible expense and delay of redesigning and retesting at the FTR.

High thermal stresses can be anticipated for nozzles or similar regions where heavy sections are used. The problem becomes more acute where materials of unlike characteristics are joined by welding. Such an example occurred on the PRTR pressurizer where nozzles are of stainless steel and the vesse1 itself is stainless clad carbon stee1. Evaluation of design adequacy was made by in-place testing under simulated normal and transient conditions. It is conceivable that, for economy, some clad or unlike materials may be used or investigated for use in the FFTF closed loops. These materials and configurations would require testing under prototypical conditions prior to use in the FTR.

Flow transients caused by loss of power, pump failure, partial blockages, and other anomalies producing coolant velocity reduction may cause stratification of the coolant, as occurred at SRE, Canoga Park, in the liquid metal heat exchangers. (10) Similar transients, possible in the closed loop piping, the heat exchangers, or other loop components, could result in excessive thermal stresses and thermal shock in the system.

Thermal stresses in interconnecting piping and other closed loop components such as connections for sampling or 
gas addition will be influenced by arrangement of the components and temperature differentials generated by loop operation. Verification of calculated stresses, evaluation of areas where calculations are extremely difficult and results are of questionable reliability, and discovery of unforeseen stress problem areas can be done most practically in a closed loop system test where pertinent variables can be produced. Also, investigation of thermal stresses and endurance testing under sustained prototypical operation will provide additional reliability assurance for the in-reactor hardware.

\section{INSULATION}

The insulating material for the FFTF closed loop will be properly specified for chemical compatibility with sodium, minimum chloride content (to avoid chloride stress corrosion of austenitic stainless steel), and insulation continuity to prevent cold spots. However, some problems may develop after installation which cannot be controlled in advance by recognized specifications, test procedures, or inspection techniques. Examples are (1) mechanical damage of insulation during thermal cycles resulting from rubbing or crushing against supports, walls, and loop equipment, and (2) inadequate space in pipe chases and other tight quarters for the placement of sufficient insulation to prevent cold spots or serious heating of local heat sensitive surfaces such as concrete or paint. The possible consequences of inadequate design and development in these areas warrant some testing on a closed loop system which is physically accurate with respect to loop piping, components, and cell boundaries, and which provides appropriate environments such as sodium and inert atmospheres.

VIBRATION

Vibration testing of in-reactor and out-of-reactor components will be an important part of the FFTF closed 1oop testing 
program. Numerous failures of reactor components and similar equipment from vibration both in and out of sodium environments are on record.(9) Fatigue from mechanical or flowinduced vibrations accounts for about $5 \%$ of the piping failures listed in Reference 9 .

Sources of vibration are numerous and include flow regulating valves, check valves, and mechanical and flow pulsations from pump vanes. As an example, the primary coolant pumps at the PRTR produce different flow rates and vibration characteristics depending on the starting procedure. Pump cavitation from a starved suction, for example, can produce high frequency, low amplitude vibrations of damaging intensity. Extreme turbulence, expected in the FFTF because of the high flow rates, can produce damaging vibrations. Such an effect was exemplified by the tube failure in the Hallam intermediate heat exchanger. (8) High sodium velocities in the secondary sodium flow were the cause of the vibration.

Because mechanical fatigue and the galling and fretting from coolant flow-induced vibration may shorten closed loop component life, vibration must be minimized. Vibration damping supports must be provided for instrument connections and similar components to eliminate, as much as possible, vibrations of a damaging frequency or amplitude. Prototypical testing will verify the adequacy of these supports and also will determine the empirical vibration characteristics of the system as a whole, including the effects of the pumps and piping configuration. While design precautions can minimize expected vibrations, only prototypical tests will determine whether the total system characteristics can produce excessive vibrations.

Dynamic testing in sodium will be performed in the closed loop system test to determine required design changes 
and to verify the adequacy of mechanical-hydraulic design characteristics. Following component pressure and flow tests with water by the vendors, endurance testing in sodium will be required to show reliability of the in-reactor hardware, interconnecting piping and disconnects, and components external to the reactor vesse 1 .

In order torealistically evaluate the problems involved, testing must be as nearly prototypical as possible. The proposed closed loop system tests will subject the in-reactor hardware to prototypical conditions in terms of pressure, temperature, thermal shock, hydraulic shock, mechanical and flowinduced vibrations, and dynamic external forces. The information gained from these tests will be required as a basis for final design of some components and final design verification of the complete system.

\section{ACCIDENT ANALYSIS}

Establishment of reactor safeguards requires a review of reactor design to assess hazards to the public and operating personnel prior to the issuance of construction and operating permits. Adherence to basic principles of safety criteria is also required. The reactor proponent is required to perform analyses showing that these safety criteria are met. These analyses may be completely analytical, be based on experimental data, or be the combined results of experimental and analytical investigations. A basic safety criterion is the requirement that the reactor system be able to sustain two independent failures without endangering the public or operating personnel. Since the closed loops will become a part of the reactor, this criterion and others must be applied to the closed loops.

Safety studies will be required for nuclear excursions, procedural errors, and coolant system failures. Topics for specific hazards analysis would be expected to include:

- In-Reactor Tube Rupture

- Primary Power Failure 
- Primary Pump Failure

- Primary System Piping Rupture

- Secondary System Piping Rupture

- Secondary System Heat Dump Failure

- Reactor Power Changes

- Primary System Flow Loss Due to Plugging

- Flow Loss Due to Gas Entrainment.

These items will require experimental analysis of both individual and combinations of individual malfunctions to meet the "two failure" criterion.

The analysis of each type of failure involves the dynamics of the complete closed loop system and the interaction of several effects. Data are necessary with respect to normal and abnormal equipment and system characteristics. Most of these characteristics are definable from component tests and analytical data. However, items judged to be particularly critical and susceptible to error caused by system variations are:

- Coolant flow rates by natural convection after complete loss of pumping power. These flow rates are strongly affected by pipe roughness, geometry, and proper valve operation. Reliable calculation is not possible because of inadequacy of friction factor data at very low mass flow rates.

Coolant flow loss resulting from gas entrainment. Such losses are sensitive to transient temperatures and pressures in the various segments of the system and are strongly system dependent.

- Rate of coolant loss following rupture of piping, pressure tube, or other components. Reliable calculation is very difficult because of possible two-phase flow from the rupture point. 
All failure studies entail localized or general heating of the primary sodium coolant beyond normal operating conditions. The characteristic of sodium that allows superheating by several hundred degrees Fahrenheit can provide a safety margin in some instances. However, the conditions controlling the level of superheating, the conditions that indicate boiling, the rate of vaporization when boiling commences, and the pressure transient during vaporization all pose difficult technical problems. Parameters possibly affecting these characteristics to an unknown extent include contact surface roughness, heat transfer surface area and roughness, sodium purity, dissolved gas in sodium, pressure level, and the presence or absence of forced convection. These variables must be quantitively defined or conservatively assumed in performing the hazards analyses to assure that any erroneous conclusions will err on the safe side. However, such conservatism could limit the reactor complex to the point where program goals could not be attained. The alternative to this approach would be the acquisition of experimental data, either in laboratory scale experiments or in full-scale, prototypical experiments. The latter is preferable for incontrovertible applicability.

Full-scale, closed loop experimentation would be expected to answer many of the problems cited above. Such experimentation would enable the use of less conservative assumptions in hazards analyses and lend greater credence to conclusions. In particular, detection of obscure effects (as, for example, detection of the loose hardware associated with the Enrico Fermi incident) and determination of system $1 \mathrm{ag}$ and time delays could be accurately factored into the accident analysis studies, or eliminated as potential trouble points. Special features incorporated in loop design for specific purposes could also be evaluated and modified as necessary to increase the probability of safe operation and attainment of desired loop life. 
System features necessary to accomplish such testing include good physical representations of equipment and piping configuration, capability to achieve design temperature and pressure conditions, and capability to introduce simulated failures without undue hazards.

REMOTE MAINTENANCE

The closed loop design requirements include the capabilities for (1) remote removal and replacement of the in-reactor tube and (2) remote removal of other major primary loop components including sodium pumps, intermediate heat exchanger tube bundles, and pump check valve internals. Extremely high radiation levels will occur in closed loop piping after performance of "run to failure" experiments. Special tools required for remote handling, decontamination, and repair of radioactive equipment will be designed, fabricated and, where possible, proof tested prior to facility startup.

Both the manipulation of components housed in the cel1 and the removal of test specimens from the pressure tube are to be accomplished by the "Radioactive Maintenance System."

The general plan for primary coolant system equipment located in the loop cells is to utilize a movable platform which can be equipped with appropriate shielding and positioned to afford the required access to loop components for the operation of remote cutters, wrenches, welders, hoists, and other equipment. The success of such a plan is strongly sensitive to the care with which piping and equipment layouts are designed, the degree of modularization employed, and the time and effort spent on designing, testing, and refining special tools and manipulative devices. Experience dictates that the consideration of remote capability as a hard-and-fast requirement will necessitate extensive design and development 
of such tools and attendant procedures to match the detailed spatial arrangement of the closed loop cell equipment. The presence of sodium, with its associated fire hazard, requires special protective features to prevent sodium leakage and to control chemical reaction. The effect of the sodium environment on welding must be evaluated from the standpoint of deposition and oxidation.

Installation requirements for accomplishing this work include a prototype of a closed loop cell complete with equipment, and effectively simulated spatial relationships. In addition, the prototype should be capable of maintaining appropriate sodium and inert gas environments to match the reactor system. Sufficient space above the test assembly should be provided to accommodate either the actual "Radioactive Maintenance System" or a prototype of this system. Development and proof testing of this system on such a prototype should not delay beneficial use of the closed loops.

\section{FUEL HANDLING AND TUBE REPLACEMENT}

It is planned to remove, inspect, and replace closed loop test specimens by routine use of the Fuel Handing Machine (FHM). Handling of test specimens is complicated because of orientation, heat removal requirements, and the susceptibility of the specimens and associated instrumentation to damage during remote mechanical manipulation. Assurance that program goals can be achieved will require extensive trial runs in which specimen assemblies are manipulated under prototypical conditions with maximum expected variation in these conditions. Such variations should include fuel pin distortion, pressure tube distortion, damaged instrumentation leads and components, and damaged test specimen positioners as we 11 as a sodium environment and postulated malfunctions of the fuel handler. The fuel handler is expected to be a large, 
heavy, complex and costly machine. As test specimen designs evolve, procedures and the mechanical capability for test specimen manipulation must be verified. Moving the handler to a prototype mockup for such in-service testing after the FFTF is commissioned and in operation would not be feasible. Therefore, the Closed Loop System Test Installation should have spatial capability for performance of mechanical fit testing to verify that the fuel handler can satisfactorily manipulate distorted in-reactor components. Although most of the required testing and development of the FHM is planned to be performed over the Reactor Cover Mockup, the proposed test installation would provide the added feature of closed loop tube and test specimen manipulation.

INSTRUMENTATION AND CONTROL

The instrumented section of the closed loop systems will require thermocouples, flow sensors, flux monitors, pressure sensors, straightening vanes, a fission gas disengagement section, and sodium sample lines. Each of these items will be individually proof tested. The assembled group of instruments and associated devices will require additional testing to ensure compatibility. The test information data should include:

- Effects of wiring tubes and flux monitor tubing on the sodium flow straightening section.

- Adequacy of assembly to withstand the vibration, temperature, and flow conditions typical of those expected in the closed loop tube.

- Assurance that the sodium sample lines will acquire an adequate sample of sodium and fission products despite other instrument obstructions in the channel.

- Measurement of the coolant pressure drop across the assembled instruments to determine the effects of flow and the consequent heat removal effciency. 
- Determination of whether close proximity of wire routing in fuel channels will induce spurious signals and whether grounding or shielding problems are present.

All designs of instrumented test assemblies should be proof tested in this manner before installation in the operating reactor.

This type of testing is dependent upon the availability of a closed loop system test environment for the final design data needed to provide units and assemblies of high quality and reliability.

Data required for the successful design of nozzle connectors to transmit instrument information from sensors in fue 1 channels to readout devices outside the reactor can be accomplished most expeditiously through the use of a Closed Loop System Test Installation. A connector carrying 35 to 40 electrical conductors, two to four gas pressure lines, and a flux monitor thimble will require the minimum integrity as follows:

- Remote separation and joining capability by fuel handling machine which may be sodium cooled.

- Large radius flux monitor thimble coupled to the fue 1 channel at the connector.

- Fit within the space on the reactor cover with 0 to 10 in. center-to-center spacing between connectors.

- Carry reactor safety circuits at $1000^{\circ} \mathrm{F}$ and maintain insulation resistance of at least 5 to $10 \mathrm{M} \Omega$.

- Connector may be required to carry a sodium sample line, with no sodium leakage, into the electrical contacts or gas 1 ine.

- Reliable nonleaking tubing connections

The Closed Loop System Test Installation would provide environments typical of those encountered in the FFTF. Improved 
confidence and reduced risk of maloperation during and after construction would result from testing in such an installation. Mockup of remote manipulator equipment for connectors would be a preferred feature of the test installation.

THERMAL HYDRAULICS

The thermal-hydraulics development plan for supporting the FFTF driver and closed 1oop fuel is presented in Reference 11. The scope of this plan covers the investigation of thermal hydraulic problems with regard to critical heat flux, fuel cladding temperature limit, fuel centerline temperature limit, local coolant voiding and propagation, loss of power and excursion accidents, and pressure drop and cross-channe 1 mixing. A11 except the pressure drop and mixing evaluation, requiring the use of bundles electrically heated in sodium, are planned to be done in the Large Heat Transfer Loop (LHTL) investigation. Pressure drop and mixing tests are planned to be done in the Hydraulic Core Mockup.

Reasons for not attempting extensive thermal-hydraulics testing on the closed loop system are (1) use of power lead wires for heating the large number of pins ( 217 ) in a prototypical fuel assembly would change the system characteristics to nonprototypical, (2) use of the closed loop system for thermal hydraulic tests would present scheduling interferences with other testing planned for it, and (3) the cost of providing power input (several megawatts) for a full size prototypical fuel element would be high, and such test sections may not be available for several years.

It is planned to investigate the the rmal hydraulic design of the closed loop by analytical work of high credibility, plus experimental verification in other loops where required for areas of particularly difficult analysis. 
The closed loop system test is needed for verifying and correlating pressure drop and cross channel mixing data obtained from water tests. Integration of this aspect of thermal hydraulics investigation would provide valuable data for design verification at minimal cost and would not significantly interfere with other tests.

NONRADIOACTIVE ISOTOPE TRANSPORT

Mass transport ${ }^{(9)}$ is a medium of failure caused by transferring material from one location to another. Examples of mass transport are the movement of corrodents, crud deposition, and carburization or decarburization.

The first example, movement of corrodent, is insignificant. So long as there is a coolant flow, the ions or solids may be moved. Crud deposition represents an example of a corrosion reaction occurring with a nonadherent corrosion produced of limited solubility. Movement of crud through the system by coolant flow does not pose a serious problem. However, precipitates, particularly colloids, will often be deposited in flow restricted areas or on the heat transfer surfaces of the fue 1 element. This deposition will adversely affect flow or heat transfer, and is thought to cause burnout in fuel elements.

Carburization or decarburization, considered possibly significant, has been observed in sodium cooled systems where both ferritic and austenitic steels are present, and also where a substantial temperature differential exists. This is normally a three-step process. The liquid sodium serves as a sink for carbon. This carbon is removed from the steel by diffusion and surface decarburization to the point where an equilibrium exists between the steel and the sodium. The laws of chemical equilibrium apply, but the flow of sodium makes calculations somewhat difficult. The sodium containing the carbon will flow through the system and redeposit the carbon on austenitic stainless 
steel in an appropriate range of temperature. Carbon in austenitic stainless steel has increased in some instances from 0.08 to nearly $2.0 \%$. Such pronounced changes, affecting the properties of the components can be prevented by proper selection of materials and adequate cleanup of the sodium.

An installation which provides either the operating parameters of FFTF or parameters which can be extrapolated to the FFTF environment can provide the foregoing data. Although not a prime function of the closed loop system test, these kinds of information could be readily generated.

\section{MECHANICAL FIT}

The compactness of the closed loop in-reactor components will create problems of mechanical fit from the close tolerances which, in the sodium environment, will be accompanied by related problems of self-welding, fretting, and galling. While these problems will be studied in other loops, the assurance that final fit-up of the system will be workable can only be demonstrated in a prototypical assembly. Similarly, endurance testing under sustained prototypical operation will be required to demonstrate design adequacy for problems of galling, selfwelding, and fretting, or to uncover potential problems not experienced in component testing programs.

It is crucial that the in-reactor channel, its attached instrument package, and associated hardware all be adequate in tolerance and alignment characteristics and perform without permanent distortion. Verifying the design adequacy and providing input for any required changes would be the primary objective of a mechanical-fit testing program. The closed Loop System Test Installation can be used to evaluate the effects of a sodium environment on wear characteristics and fit characteristics after sustained operation and handing. Mechanical fit also can influence the amplitude of vibration. 
The adequacy of the design to maintain adequate fit for vibration damping characteristics in a sodium environment can be studied for verification and modifications.

Other related problems which should be studied in the closed loop system test as a part of mechanical-fit testing involve the effects on gaskets or joints subject to repeated assembly and disassembly, potential leak points from such areas, and the accessibility of components for maintenance. Another problem of this nature concerns possible gasket extrusion into the process channel and consequent fuel element hang-up during fueling operations. Such closed loop problems can be done advantageously eliminated by a closed loop system test.

Other information such as compatibility and operability of individual components, assembly sequence, space and reliability requirements for out-of-reactor hardware, and fit of top face components operating as an integrated system can be gained from a closed loop system test.

COOLANT PURITY CONSIDERATIONS

Planned at LMEC and other sites are extensive coolant chemistry research and development programs entailing 1 aboratory and small test loop experimentation for the investigation of corrosion by sodium environments, carbon-oxygen-radioactive isotope transport, coolant purity instrumentation, and coolant treatment for purification. A secondary aspect of the FFTF operation is the introduction or generation of solid particulate contaminants. The FFTF closed loops are particularly susceptible to the introduction of solid impurities because of the routine frequency of test specimen changeout and the probable need for periodic replacement. The possible presence of solid particulates resulting from modifications or construction involving grinding and welding, could undoubtedly be prevented by precautionary measures. 
Solid particulates present in the system could possibly lodge in a test specimen assembly and partially or totally block the coolant channel and cause fuel overheating. Deposition of solids in areas of low flow rates and low pressure drops in the external coolant system could significantly change the system hydraulic characteristics and cause equipment malfunction.

Appropriate use of a Closed Loop System Test Installation will permit analytical calculations defining points of relative fluid stagnation or restrictive flow geometry (where settling is probable) and thus assist in identifying and correcting critical areas and regions susceptible to solids deposition.

The presence of gaseous impurities in closed loop cover gas and coolant systems must be detected in order to effect control. Chromatographic detection of oxygen, nitrogen, and hydrogen levels associated with sodium coolants at FFTF closed loop conditions cannot be accomplished with stock hardware. A Closed Loop System Test Installation would provide the necessary features of temperature, flow, pressure, and sampling modes to properly test, calibrate, and evaluate purity detection and control of a sodium environment.

\section{OPERATIONAL BENEFITS OF CLOSED LOOP SYSTEM TESTING}

The potential uses and needs for closed loop system tests prior to reactor startup are significant. Experience has demonstrated that problems of an operational nature, unforeseen inadequate equipment performance resulting from obscure effects or phenomena, development of maintenance techniques and procedures to fit special circumstances, and operating personnel training require sustained attention. Furthermore, in the relatively complex FFTF system, such areas are likely to present greater problems than would be the case for a less technologically advanced system. These areas and their relationship to the proposed Closed Loop System Test Installation are discussed in the following paragraphs. 


\section{OPERATING PROCEDURES}

One of the tasks facing the FFTF operating contractor is the preparation of detailed operating procedures. The coverage will range from day-to-day routine operations to emergency procedures in which the sequence or timing of a series of manual operations is critical. When questions on procedures of the latter nature arise, it has been customary to develop a procedure based on test information obtained on the subject system while the facility is shut down. The penalty for such an approach is reduced operating efficiency. In the case of the FFTF and its multiple closed loops, the combination of the goal operating efficiency and the inherent system complexities would appear to be incompatible with this approach. The following examples taken from other reactor development programs appear to be applicable to the FFTF closed 10ops:

- Normal and emergency procedures for fuel element cooling during discharge

- Activation of "last ditch" emergency cooling system (i.e., convective cooling)

- Routine measurement of test specimen hydraulic characteristics prior to installation in-reactor

- Verification of hardware (such as orifices) which generate necessary hydraulic characteristics for new test specimens

- Verification of coolant drainage procedure

- Verification of loop heat-up procedure

- Resolution of descrepancies between specified equipment function and actual function

- Development of decontamination procedures with respect to draining, venting, introduction of decontaminant, and return to service

- Checkout of proposed modifications. 
Most of such items are amenable to resolution in a closed loop system test concurrent with reactor operation. A satisfactory test installation should be dimensionally similar to produce system dynamics identical with installed systems and to serve as a ready mockup for evaluation of spare parts.

UNFORESEEN PROBLEMS

The general goal of LMFBR development programs is the development and demonstration of fast breeder reactor technology for civilian power production. Inasmuch as the FFTF program is devoted to research and development, unforeseeable problems will, as in similar programs, undoubtedly arise. Typical examples of such problems, with respect to FFTF closed loop operation, are:

- Chronic valve (plug-seat) and stem leakage

- Disengagement of test section components

- Fretting corrosion within in-reactor assembly

- Vibrational fatigue of auxiliary line connections (instruments, drains, vents)

- Disengagement of valve actuators from valve stems

- Electrical heater system imbalance

- Cold trap operation

- Cover gas problems

- Sample line plugging

- Instrument reliability.

While solution of such problems may be guided by logic, an empirical approach is ultimately required to identify potential solutions, and to select, implement, and verify those appearing to offer the greatest advantages. In the latter phase, the implementation is normally carried out on the facility itself, often at significant expense to operating efficiency. A case illustrating the effectiveness of an out-of-reactor test 1oop is the Plutonium Utilization program providing the Plutonium Recycle Test Reactor (PRTR). During its 10 yr program, the 
Equipment Development Experimental Loop (EDEL) in the 314 Building (a prototype PRTR fuel channel) has been extensively used to solve problems in vibration, fretting corrosion, fuel element assembly mechanical integrity, and primary pump seal problems.

MAINTENANCE

The FFTF closed loop experimental ptogram calls for irradiation of test specimens to failure. Furthermore, means are to be provided for recovery from a test specimen meltdown. Each such incident may require complete remote maintenance because of high radiation levels and may be somewhat unique with respect to fuel cooling and removal techniques. A Closed Loop System Test Installation would be invaluable in preparing for these contingencies prior to such incidents.

A type of potential predicament was exemplified by the PRTR Rupture Loop Incident in which a fuel element failure caused the failure of the loop in-reactor pressure tube. Fuel debris in this instance was washed into the calandria (similar to the FFTF driver bed) and into all external loop piping. In spite of extreme efforts on the part of maintenance, operating, and engineering personnel, some 10 months were required for restoration of the reactor to operating status. Much of that time was spent in constructing special equipment and tools suitable to the particular situation, mockups for trial runs, and development of appropriate procedures. The availability of a complete physical closed loop test system would have reduced significantly the time needed to restore the reactor.

\section{OPERATING EXPERIENCE}

In a complex closed loop system such as the FFTF, a high level of personnel competence is required for safe and efficient operation of the facility. Qualification procedures should require sound theoretical knowledge and entail physical 
trial runs in particularly sensitive operations. Much of such training could be accomplished on the actual facilities. However, implementation of such a procedure could interfere with construction and/or delay the initial reactor closed loop startup. The value of the closed loop system for training, although difficult to quantitatively assess, would be significant.

\section{QUALITY ASSURANCE}

Repeated use of FFTF quality assurance practices and specifications is expected to result in a higher level of performance by designers, craftsmen, and inspectors. Experience gained in providing a Closed Loop System Test Installation will enhance the quality of later performance in design, procurement, fabrication, construction, and use of the actual FFTF.

\section{SYSTEM TEST ENVIRONMENTAL REQUIREMENTS}

The applicable requirements for quality assurance in design, procurement, fabrication, and construction of the Closed Loop System Test Installation will be selected from the program requirements of BNWL-511, A-0018R, BNWL-593, and BNWL-630, and specified by the designer in PNL instructions and contracts. Those components essential to the prevention of accidents shall be designed, fabricated, and erected to quality standards reflecting the degree of importance of the function to be performed.

The various environments and associated levels required of the Closed Loop System Test Installation are summarized below. The environments are grouped into in-reactor and out-of-reactor categories for clarity.

For maximum nonnuclear simulation, the following in-reactor environments are required of the Closed Loop System Test Installation. 
- A simulated reactor $\Delta T$ with an ultimate capability of attaining $850^{\circ} \mathrm{F}$ reactor inlet temperature and $1200^{\circ} \mathrm{F}$ reactor outlet temperature

- A simulated reactor pressure of 140 psig inlet and 10 psig outlet

- A simulated reactor vertical $\Delta \mathrm{P}$ with an ultimate capability of attaining 100 psid

- Localized reactor flow velocities of $2 \mathrm{ft} / \mathrm{sec}$ maximum parallel to the in-reactor closed loop tube and $10 \mathrm{ft} / \mathrm{sec}$ maximum perpendicular to the tube

- Flow external to the in-reactor tube to $1000 \mathrm{gpm}$

- A simulated reactor coolant media of liquid sodium

- A simulated reactor cover gas of helium or argon

- An in-reactor tube radial $\Delta \mathrm{T}$ of $550^{\circ} \mathrm{F}$ maximum

- An in-reactor tube vertical $\triangle \mathrm{T}$ of $350^{\circ} \mathrm{F}$ maximum, and ultimate inlet and outlet temperatures to 850 and $1200^{\circ} \mathrm{F}$, respectively

- Test specimen heat of $6 \mathrm{MW}_{t}$

- Reactor coolant chemistry capable of maintaining sodium to reactor grade specifications

- Reactor temperature transients of 1100 to $900^{\circ} \mathrm{F}$ at $\sim 50{ }^{\circ} \mathrm{F} / \mathrm{sec}$. The following out-of-reactor environments are also required of the test installation:

- Closed loop system coolant media of liquid sodium

- Primary closed loop cell gas of nitrogen

- Simulated hot cell gas of air and/or nitrogen

- Mechanical induced vibration from rotating machinery

- Primary closed 1oop system $\Delta \mathrm{P}$ of 200 psid

- Secondary closed 1oop system $\Delta \mathrm{P}$ of 35 psid

- Closed loop system $\Delta \mathrm{T}$ of $350^{\circ} \mathrm{F} \operatorname{maximum}$ (from 850 to $1200^{\circ} \mathrm{F}$ )

- Maximum closed loop system heat removal capacity of $6 \mathrm{MW}_{t}$ 
- System layout and equipment necessary to perform remote handling and maintenance

- Primary closed loop system flow to $600 \mathrm{gpm}$

- Secondary closed loop system flow to $1000 \mathrm{gpm}$

- Closed loop system coolant chemistry capable of maintaining closed loop grade sodium $(\leq 5 \mathrm{ppm}$ carbon, $\leq 5 \mathrm{ppm}$ oxygen)

- In-reactor tube internal temperature transients to $1100^{\circ} \mathrm{F}$ : at $100^{\circ} \mathrm{F} / \mathrm{sec}$ (reactor scram).

\section{CONCEPTUAL TEST PLAN AND SCHEDULE}

The conceptual test plan presented in the following paragraphs is dependent on the scope of the system test concept that is selected and ultimately built. To present a meaningful system test plan, it has been assumed that the recommended Alternate III testing capabilities will be made available. Alternates $I$ and $I I$ would require additions to the test $p 1$ an, while Alternates IV, $V$, and VI would require deletions.

The plan is divided into preoperational, steady state, transient, remote operations, accelerated life, and decontamination testing phases, and then subdivided into individual tests within the phases. A test objective and the measured variables of each test are described in this preliminary test plan. A detailed test plan will be developed when the closed loop design and test installation concepts have been approved. PREOPERATIONAL TESTING

Activities to be initiated prior to the introduction of sodium:

\section{- Inert Gas System Checkout}

Test Objective--To prepare the inert gas system for operation and to determine that system and related system components function per design specifications. 
Measured Variables--Flow, temperature, pressure purge rates, purge volume, time and leakage rates. Preheating System Checkout

Test Objective--To verify that the sodium pipe and equipment preheating system operates satisfactorily and preheats all sodium systems so they can be filled with sodium, Measured Variables--Temperature, preheat time, heater con. trol, control response times, and allowable $\Delta \mathrm{T}$. Sodium Leak Detection System Checkout

Test Objective-.To verify that the sodium leak detection system is capable of detecting sodium leakage in the vicinity of the detector.

Measured Variables--Operating voltage, current, circuit continuity, insuiation resistant, short across the detector, and calibration.

Lighting, Power, and Communication Checkout

Test Objective--To verify that the lighting, power, and communication systems operate satisfactorily.

Measured Variables--Voltage, current, circuit continuity, insulation resistance, frequency and response time.

Contro: System Checkout

Test Objective--To verify that each closed loop control subsystem is operable

Measured Variables-Voltage, current, circuit continuity, and insulation resistance.

- Sodium System Purge

Test Objective--To establish an inert gas atmosphere in the sodium loops.

Measured Variables--Flow, temperature, pressure, impurity content, purge time, inert gas quantity required, and moisture content. 
Activities to be initiated during and after the introduction of sodium:

- Sodium Service System Checkout

Test Objective--Determine that the sodium service system is adequately prepared for purging, filling, and subsequent circulating operations, and that no distress or binding is caused by preheating.

Purge the sodium service system with helium and verify that the sodium fill tanks and associated purification equipment contain helium atmosphere of less than $1 \%$ oxygen concentration.

Fil1 the sodium fill tanks and verify the operability of the equipment which is used to perform this operation.

Verify that the sodium service system piping can be filled with sodium from the fill tanks, and that sodium can be circulated through the system plugging meters, cold traps, and carbon trap. Determine the operating characteristics of the plugging meters, cold traps, and carbon trap by putting these components into service with use of the service pumps. Also, verify that the purification systems control subsystem is operable and adequate.

Measured Variables--Leakage, pressure, temperature, flow inert gas purity, plugging temperature, sodium purity, and fill time.

- Initial Fill of Main Sodium Loops

Test Objective--To verify that the sodium loops can be filled safely and efficiently and to determine the volume of sodium required. Measured Variables--Temperature pressure volume, fil1 time, and sodium elevation. 
- In-Line Heater Checkout

Test Objective--To verify the proper rating, location, circuitry, switching, relaying, and operation of in-line heaters.

Measured Variables--Voltage, current, temperature, flow, pressure, heating time, circuit continuity, and insulation resistance

\section{STEADY-STATE TESTING}

System Hydraulics

Test Objective--To determine the hydraulic characteristics of the closed loop primary and secondary systems. Verify that the system could be expected to operate satisfactorily under normal operating conditions and establish hydraulic parameters for comparison with data to be taken during transient operation. This test will be performed in two parts: (1) isothermal operation and (2) power operation. Measured Variables--Pump speed, current, voltage, leakage, flow, mechanical forces, vibration, strain, temperature, solids deposition pressure, and pipe displacement.

- Heat Transfer

Test Objective--To verify system performance at each incremental power level. Establish heat transfer data for comparison with the calculated. Resultant performance data will be plotted and permanently retained for future comparative purposes in analyzing closed loop system performance.

Measured Variables--Voltage, temperature, pressure, flow, and power.

- Closed Loop System Control

Test Objective--To verify that the closed loop control subsytems are properly operable as a compatible, integrated system throughout the range of reactor operation. This test will include pump shutdown and switchover. 
Measured Variables--Flow, pressure, temperature, pump speed, power flow signal voltage, pump operating time history, noise level, response time, and coolant purity level control.

\section{TRANS IENT TESTING}

- Simulated Scram

Test Objective--To verify that the closed loop system will function properly and safely during the transient conditions of scram. Incremental power level scrams will be investigated.

Measured Variables--Temperature, pressure, flow, gas impurity, vibration, valve position, strain, pump speed, and power.

- Power Surge

Test Objective--To verify that the closed loop system will function properly and safely during simulated component or piping failures.

Measured Variables--Temperature, pressure, flow, gas impurity, vibration, valve position, strain, pump speed, and power.

\section{REMOTE OPERATIONS TESTING}

- Remote Maintenance of Closed Loop Equipment

Test Objective--To verify that the remote maintenance equipment design is adequate to service such components as the pump, heat exchanger, tube section, and valves Measured Variables--Temperature, pressure, galling and fretting damage, tolerance and alignment of critical areas, integration capabilities of loop components, voltage current, cutting speed, source strength, geometry, and distance. 
- Remote Handling of Radioactive Components

Test Objective--To verify that the remote handling equipment design is adequate.

Measured Variables--Voltage, current, speed, and handling time .

- Fue 1 Handling of Dummy Test Specimen

Test Objective--To verify that the fuel handling equipment design is adequate to handle the test specimen fuel. Measured Variables--Voltage, current, speed, withdrawal and insertion forces, galling, and sequence time.

\section{ACCELERATED LIFE TESTING}

- Thermal Cycle

Test Objective--To verify that the closed loop systems will function properly and safely through the number of cycles predicted over the life of the reactor. Me asured Variables--Temperature, pressure, number of cycles, strain, and flow.

- Gas Entrainment

Test Objective--To verify that the closed loop system will function properly at various gas entrainment levels. Measured Variables--Temperature, pressure, flow, coolant purity, and level of introduced gas affecting operation.

- Mechanical Cycles

Test Objective--To verify that all mechanical and electrical equipment will function properly and safely through the number of cycles predicted over the life of the loop. Measured Variables--Voltage, current, speed, number of cycles, noise, and wear.

\section{DECONTAMINATION TESTING}

- Purity Experimentations

Test Objective-To verify that excessive nonirradiated and irradiated crud depletion and deposition does not exist in critical components of the system. 
Measured Variables--Coolant flow rates and temperature, carburization and decarburization, distribution of deposition, and decontamination characteristics.

\section{ALTERNATE SYSTEM TEST CONCEPTS}

The closed loop system test should be capable of simulating as many of the anticipated environments as can be possibly justified. To be consistent with the overall FFTF program, the installation will be governed by both time and capital available. The simulation of some of the environments is limited on the basis of personnel safety and current technology. The particular environments of concern and the key features of the alternate concepts are 1 isted in Tables II and III, and the related cost estimates are 1 isted in Table IV. For ease of discussion, the environments have been subdivided into "In-Reactor" and "Out-of-Reactor."

The following system test installation concepts have been considered.

\section{ALTERNATE I}

Alternate I features are shown in Figure 2 (SK-3-14177). This alternate consists of completely prototypical primary and secondary closed loops, a reactor simulation 100 , and sodium purification systems for the three loops.

The completely prototypical primary and secondary loops provide the features necessary to investigate out-of-reactor thermal stresses, thermal ratcheting, insulation, remote decontamination and maintenance, mechanical and hydraulic vibrations, gas entrainment, mass transport, system and subsystem pressure drops, heat transfer coefficients, insulation, and stratification of coolant on all the components and piping. As the loops become less prototypical, the quantity and quality of the data are compromised. The prototypical nitrogen environment of the primary loop cel1 is also required to demonstrate remote maintenance capabilities. 
TABLE II. Possible Alternates for Closed Loop System Test Installation (In-licactor)

\begin{tabular}{|c|c|c|c|c|c|c|c|c|}
\hline Envi ronment & FTR Levels & $\begin{array}{c}\text { Installation } \\
\text { Test } \\
\text { Requirement } \\
\end{array}$ & $\begin{array}{c}\text { Alternate } \\
1\end{array}$ & $\begin{array}{c}\text { Alternate } \\
11\end{array}$ & $\begin{array}{c}\text { Alternate } \\
\text { Ill }\end{array}$ & $\begin{array}{c}\text { Niternatc } \\
\text { IV }\end{array}$ & $\underset{V}{\text { Alternate }}$ & $\begin{array}{c}\text { Hermate } \\
11\end{array}$ \\
\hline $\begin{array}{l}\text { Reactor } \Delta T \\
\text { (Ult imate) }\end{array}$ & $\begin{array}{l}850-1200{ }^{\circ} \mathrm{F} \\
\text { maximum }\end{array}$ & $\begin{array}{l}850-12000^{\circ} \mathrm{F} \\
\text { maximum }\end{array}$ & $\begin{array}{l}850-1200{ }^{\circ} \mathrm{F} \\
\operatorname{maxi} \operatorname{mum}\end{array}$ & $\begin{array}{l}850-1200^{\circ} \mathrm{F} \\
\text { maximum }\end{array}$ & $\begin{array}{l}850-1200^{\circ} \mathrm{F} \\
\operatorname{maximum}\end{array}$ & None & vone & rone \\
\hline $\begin{array}{l}\text { Reactor } \\
\text { Pressure }\end{array}$ & $\begin{array}{l}140 \mathrm{psig} \text { inlet } \\
10 \text { psig outlet }\end{array}$ & $\begin{array}{l}140 \mathrm{psig} \text { inlet } \\
10 \mathrm{psig} \text { out } 1 \mathrm{et}\end{array}$ & $\begin{array}{l}70 \mathrm{psig} \text { inlet } \\
10 \mathrm{psig} \text { outlet }\end{array}$ & $\begin{array}{l}70 \mathrm{psig} \text { inlet } \\
10 \mathrm{psig} \text { outlet }\end{array}$ & $\begin{array}{l}45 \text { psig inlet } \\
10 \text { psig outlet }\end{array}$ & Atmospheric & Atmospheric & Atmospheric \\
\hline React or $A P$ & 60 to $100 \mathrm{psid}$ & $\begin{array}{l}60 \text { to } 100 \text { psid } \\
\operatorname{maximum}\end{array}$ & $\begin{array}{l}60 \mathrm{psid} \\
\text { maximum }\end{array}$ & $\begin{array}{l}60 \text { psid } \\
\text { maximum }\end{array}$ & $\begin{array}{l}35 \text { psid } \\
\text { maximum }\end{array}$ & None & None & Nonk \\
\hline $\begin{array}{l}\text { Reactor } \\
\text { Flow } \\
\text { Velocity }\end{array}$ & $\begin{array}{l}+2 \mathrm{ft} / \mathrm{sec} ; \\
+10 \mathrm{ft} / \mathrm{sec}\end{array}$ & $\begin{array}{l}+2 \mathrm{ft} / \mathrm{sec} \\
-10 \mathrm{ft} / \mathrm{sec}\end{array}$ & $\begin{array}{l}+2 \mathrm{ft} / \mathrm{sec} \\
+10 \mathrm{ft} / \mathrm{sec}\end{array}$ & $\begin{array}{l}+2 \mathrm{ft} / \mathrm{sec} \\
+10 \mathrm{ft} / \mathrm{sec}\end{array}$ & $\begin{array}{l}\text { Mechanically } \\
\text { induced } \\
\text { vibration }\end{array}$ & $\begin{array}{l}\text { Mechanically } \\
\text { induced } \\
\text { vibration }\end{array}$ & None & Sone \\
\hline $\begin{array}{l}\text { Flow } \\
\text { External } \\
\text { to Tube }\end{array}$ & $1000 \mathrm{gpm}$ & $1000 \mathrm{gpm}$ & $2000 \mathrm{gpm}$ & $2000 \mathrm{gpm}$ & $30 \mathrm{gpm}$ & None & Nonc & rone. \\
\hline $\begin{array}{l}\text { Reactor } \\
\text { Cool ant } \\
\text { Media }\end{array}$ & Sodium & Sodium & Sodium & Sodium & Sodium & Air & Air & $\operatorname{sir}$ \\
\hline $\begin{array}{l}\text { Reactor } \\
\text { Cover Gas }\end{array}$ & He or $\mathrm{Ar}$ & He or Ar & $\mathrm{He}$ or $\mathrm{Ar}$ & $\mathrm{He}$ or $\mathrm{Ar}$ & lie or $\mathrm{Ar}$ & $\wedge \mathrm{ir}$ & Ai $\mathbf{r}$ & $\Lambda \mathrm{ir}$ \\
\hline $\begin{array}{l}\text { In-pile } \\
\text { Tube } \\
\text { Radial } \Delta T\end{array}$ & $\begin{array}{l}550^{\circ}{ }^{\circ} \mathrm{F} \\
\operatorname{maxi} \text { mum }\end{array}$ & $\begin{array}{l}550^{\circ}{ }^{\circ} \mathrm{F} \\
\operatorname{maxi} \operatorname{mum}\end{array}$ & $\begin{array}{l}550^{\circ} \mathrm{F} \\
\operatorname{maxi} \text { mum }\end{array}$ & $\begin{array}{l}550^{\circ} \mathrm{F} \\
\operatorname{maximum}\end{array}$ & $\begin{array}{l}550^{\circ} \mathrm{F} \\
\operatorname{maximum}\end{array}$ & $\begin{array}{l}550^{\circ}{ }^{\circ} \mathrm{F} \\
\operatorname{maximum}\end{array}$ & $\begin{array}{l}550^{\circ} \mathrm{F} \\
\operatorname{maximum}\end{array}$ & 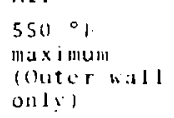 \\
\hline $\begin{array}{l}\text { Test } \\
\text { Specimen } \\
\text { lieat }\end{array}$ & 6 MN & $6 \mathrm{MK}$ & $100 \mathrm{~kW}$ & $100 \mathrm{~kW}$ & $100 \mathrm{~kW}$ & $100 \mathrm{kk}$ & $100 \mathrm{kH}$ & None \\
\hline $\begin{array}{l}\text { Neut ron } \\
\text { Flux }\end{array}$ & $\begin{array}{l}1 \times 10^{16} \\
\mathrm{n} / \mathrm{cm}^{2} / \mathrm{sec}\end{array}$ & None & None & None & None & None & Nene & xone \\
\hline $\begin{array}{l}\text { In-pile } \\
\text { Tuhe } \\
\text { Vertical it }\end{array}$ & $850-1200^{\circ} \mathrm{F}$ & $850-1200^{\circ} \mathrm{F}$ & $850-1200{ }^{\circ} \mathrm{F}$ & $850-1200^{\circ} \mathrm{F}$ & $850-12000^{\circ}=$ & $850-12000^{\circ} \mathrm{F}$ & $8501-1200^{\circ} \mathrm{F}$ & None \\
\hline
\end{tabular}


TABLE III. Possible Alternates for Closed Loop System Test Installation (Out-of-Reactor)

\begin{tabular}{|c|c|c|c|c|c|c|c|c|}
\hline Environment & FTR Levels & $\begin{array}{c}\text { Installation } \\
\text { Test } \\
\text { Requirement } \\
\end{array}$ & Alternate & $\begin{array}{c}\text { Alternate } \\
\text { II }\end{array}$ & Alternate & $\begin{array}{c}\text { Al ternate } \\
\text { IV } \\
\end{array}$ & $\underbrace{\text { Alte rnate }}_{V}$ & $\begin{array}{c}\text { Alternate } \\
\text { VI }\end{array}$ \\
\hline $\begin{array}{l}\text { Closed Loop } \\
\text { Coolant } \\
\text { Mcdia }\end{array}$ & Sodium & Sodium & Sodium & Sodium & Sodium & Sodium & Sodi um & Sodium \\
\hline $\begin{array}{l}\text { Primary } \\
\text { Loop Cell } \\
\text { Gas }\end{array}$ & Nitrogen & Nitrogen & Nitrogen & Nitrogen & Nitrogen & Air & $A i r$ & Air \\
\hline $\begin{array}{l}\text { Ce11 } \\
\text { Inert Gas }\end{array}$ & $\mathrm{Air}$ and $\mathrm{N}$ & $\mathrm{Air}$ and $\mathrm{N}$ & Air and $N$ & Air and $N$ & Air and $N$ & $\mathrm{Air}$ and $\mathrm{N}$ & $A i r$ and $N$ & Air and $N$ \\
\hline $\begin{array}{l}\text { Mechani- } \\
\text { cally } \\
\text { Induced } \\
\text { vibration }\end{array}$ & $\begin{array}{l}\text { Rotating } \\
\text { Machinery }\end{array}$ & $\begin{array}{l}\text { Rotating } \\
\text { Machinery }\end{array}$ & Prototypic & $\begin{array}{l}\text { Prototypic } \\
\text { Primary Loop }\end{array}$ & $\begin{array}{l}\text { Prototypic } \\
\text { Primary Loop }\end{array}$ & Nonprototypic & Nonprototypic & $\begin{array}{l}\text { Single } \\
\text { Pump }\end{array}$ \\
\hline $\begin{array}{l}\text { Closed Loop } \\
\text { System } \Delta T\end{array}$ & & & & & & & & \\
\hline $\begin{array}{l}\text { Primary } \\
\text { Secondary }\end{array}$ & $\begin{array}{r}200 \text { psid } \\
35 \text { psid }\end{array}$ & $\begin{array}{r}200 \text { psid } \\
35 \text { psid }\end{array}$ & $\begin{aligned} 200 & \text { psid } \\
35 & \text { psid }\end{aligned}$ & $\begin{array}{r}200 \text { psid } \\
35 \text { psid }\end{array}$ & $\begin{array}{r}200 \mathrm{psid} \\
35 \mathrm{psid}\end{array}$ & $\begin{array}{r}200 \mathrm{psid} \\
35 \mathrm{psid}\end{array}$ & $\begin{aligned} 200 & \text { psid } \\
35 & \text { psid }\end{aligned}$ & $\begin{aligned} 200 & \text { psid } \\
0 & \text { psid }\end{aligned}$ \\
\hline $\begin{array}{l}\text { Closed Loop } \\
\text { System } \Delta T \\
\text { (U1timate) }\end{array}$ & $850-1200^{\circ} \mathrm{F}$ & $850-1200{ }^{\circ} \mathrm{F}$ & $850-1200^{\circ} \mathrm{F}$ & $850-1200^{\circ} \mathrm{F}$ & $850-1200^{\circ} \mathrm{F}$ & $850-1200^{\circ} \mathrm{F}$ & $850-1200^{\circ} \mathrm{F}$ & $850-1200^{\circ}$ \\
\hline $\begin{array}{l}\text { Maximum } \\
\text { Heat } \\
\text { Removal } \\
\text { Capacity }\end{array}$ & $6 \mathrm{MW}$ & $6 \mathrm{MW}$ & $6 \mathrm{MK}$ & $6 \mathrm{MW}$ & $6 \mathrm{MW}$ & $100 \mathrm{~kW}+\mathrm{P} . \mathrm{H}$. & $100 \mathrm{~kW}+$ P.H. & $100 \mathrm{~kW}+\mathrm{p}$ \\
\hline $\begin{array}{l}\text { Remote } \\
\text { Mainte- } \\
\text { nance }\end{array}$ & Yes & Yes & Yes & Yes & Yes & Yes & Yes & Limited \\
\hline $\begin{array}{l}\text { Closed Loop } \\
\text { System Flow } \\
\text { Primary } \\
\text { Secondary }\end{array}$ & $\begin{array}{l}600 \mathrm{gpm} \\
1000 \mathrm{gP \pi}\end{array}$ & $\begin{array}{l}600 \mathrm{gpm} \\
1000 \mathrm{gpm}\end{array}$ & $\begin{array}{l}600 \mathrm{gpm} \\
1000 \mathrm{gpm}\end{array}$ & $\begin{array}{l}600 \mathrm{gpm} \\
1000 \mathrm{gpm}\end{array}$ & $\begin{array}{l}600 \mathrm{gpm} \\
1000 \mathrm{gpm}\end{array}$ & $\begin{array}{l}600 \mathrm{gpm} \\
1000 \mathrm{gpm}\end{array}$ & $\begin{array}{l}600 \mathrm{gpm} \\
1000 \mathrm{gpm}\end{array}$ & $\begin{array}{rl}600 & \mathrm{gpm} \\
0 & \mathrm{gpm}\end{array}$ \\
\hline $\begin{array}{l}\text { CLS } \\
\text { Ceolant } \\
\text { Chemistry }\end{array}$ & $\begin{array}{l}\text { Closed } \\
\text { Loop } \\
\text { Grade }\end{array}$ & $\begin{array}{l}\text { Closed } \\
\text { Loop } \\
\text { Grade }\end{array}$ & $\begin{array}{l}\text { Closed } \\
\text { Loop } \\
\text { Grade }\end{array}$ & $\begin{array}{l}\text { Closed } \\
\text { Loop } \\
\text { Grade }\end{array}$ & $\begin{array}{l}\text { Closed } \\
\text { Loop } \\
\text { Grade }\end{array}$ & $\begin{array}{l}\text { Closed } \\
\text { Loop } \\
\text { Grade }\end{array}$ & $\begin{array}{l}\text { Closed } \\
\text { Loop } \\
\text { Grade }\end{array}$ & $\begin{array}{l}\text { Closed } \\
\text { Loop } \\
\text { Grade }\end{array}$ \\
\hline $\begin{array}{l}\text { Tube } \\
\text { Internal } \\
\text { Pressure } \\
\text { Transient }\end{array}$ & $10.000 \mathrm{Dsi}$ * & None & None & Vone & None & None & None & None \\
\hline $\begin{array}{l}\text { Tube } \\
\text { Internal } \\
\text { Temperature } \\
\text { Transient }\end{array}$ & $\begin{array}{l}1400-11000^{\circ} \mathrm{F} \\
\text { at } 1000^{\circ} \mathrm{F} / \mathrm{sec}\end{array}$ & $\begin{array}{l}1400-11000^{\circ} \mathrm{F} \\
\text { at } 100^{\circ} \mathrm{F} / \mathrm{sec}\end{array}$ & None & None & None & None & None & None \\
\hline $\begin{array}{l}\text { Reactor } \\
\text { Coolant } \\
\text { Chemistry }\end{array}$ & $\begin{array}{l}\text { Reactor } \\
\text { Grade }\end{array}$ & $\begin{array}{l}\text { Reactor } \\
\text { Grade }\end{array}$ & $\begin{array}{l}\text { Reactor } \\
\text { Grade }\end{array}$ & $\begin{array}{l}\text { Reactor } \\
\text { Grade }\end{array}$ & $\begin{array}{l}\text { Reactor } \\
\text { Grade }\end{array}$ & None & None & None \\
\hline $\begin{array}{l}\text { Reactor } \\
\text { Pressure } \\
\text { Transients }\end{array}$ & No Data & None & None & None & None & None & None & None \\
\hline $\begin{array}{l}\text { Reactor } \\
\text { Temperature }\end{array}$ & $\begin{array}{l}1100-900^{\circ} \mathrm{F} \\
\text { at } 2.50^{\circ} \mathrm{F} / \mathrm{sec}\end{array}$ & $\begin{array}{l}1100-9000^{\circ} \mathrm{F} \\
\text { at } 250^{\circ} \mathrm{F} / \mathrm{sec}\end{array}$ & vene & None & None & None & None & None \\
\hline
\end{tabular}




\begin{tabular}{|c|c|c|c|c|c|}
\hline \multirow[b]{3}{*}{ Alternate } & \multicolumn{4}{|c|}{$\begin{array}{l}\text { Cost Estimate of Proposed } \\
\text { Alternate Test Installations }\end{array}$} & \multirow[b]{3}{*}{$\begin{array}{c}\text { New Bldg. } \\
\text { Costs }\end{array}$} \\
\hline & \multicolumn{4}{|c|}{ Direct Costs, $\$$} & \\
\hline & $\begin{array}{l}\text { Reactor } \\
\text { Simulation } \\
\text { Loop }\end{array}$ & $\begin{array}{l}\text { Primary } \\
\text { Loop }\end{array}$ & $\begin{array}{c}\text { Secondary } \\
\text { Loop }\end{array}$ & $\begin{array}{l}\text { Total } \\
\text { Equipment } \\
\text { Direct } \\
\text { Costs }\end{array}$ & \\
\hline$I$ & $\$ 3,399,280$ & $1,500,610$ & 707,550 & $5,607,440$ & $1,159,000$ \\
\hline I I & $1,370,590$ & $1,500,610$ & 628,860 & $3,500,060$ & 785,000 \\
\hline I I I & 515,210 & $1,500,610$ & 565,940 & $2,581,760$ & 785,000 \\
\hline IV & & $1,167,580$ & 707,550 & $1,875,130$ & $1,159,000$ \\
\hline $\mathrm{V}$ & & 940,260 & 268,920 & $1,209,180$ & 525,000 \\
\hline VI & & 580,310 & & & 337,000 \\
\hline
\end{tabular}

This alternative attempts to combine simulated test specimen heat and full system heat capacity by providing a $100 \mathrm{~kW}$ in-tube test specimen heat simulation (Item 42) and an out-of-reactor 6 MW heat simulation (Item 63) in Figure 2 (SK-3-14177). At low flows the $100 \mathrm{~kW}$ heater will provide some radial $\Delta \mathrm{T}$ simulation capability. At full system flow a 6 MW heater will provide the heat necessary to evaluate the rest of the system.

A cold tank will be manifolded with the 6 MW heater to simulate normal thermal transients, such as reactor scrams. Flow control valves and an auxiliary pump will be used with the tank and heater to provide the capability of varying thermal response times.

The reactor simulation loop will provide a wide variety of environmental conditions. This loop will be capable of simulating vessel vertical total $\Delta \mathrm{P}$ above the upper grid plate. Therefore, the radial pressure profile to which the closed loop tube will represent an overtest below the upper grid plate.

The loop also will be capable of simulating reactor vertical $\Delta \mathrm{T}$ at full flow capacity. This feature is desirable in the 


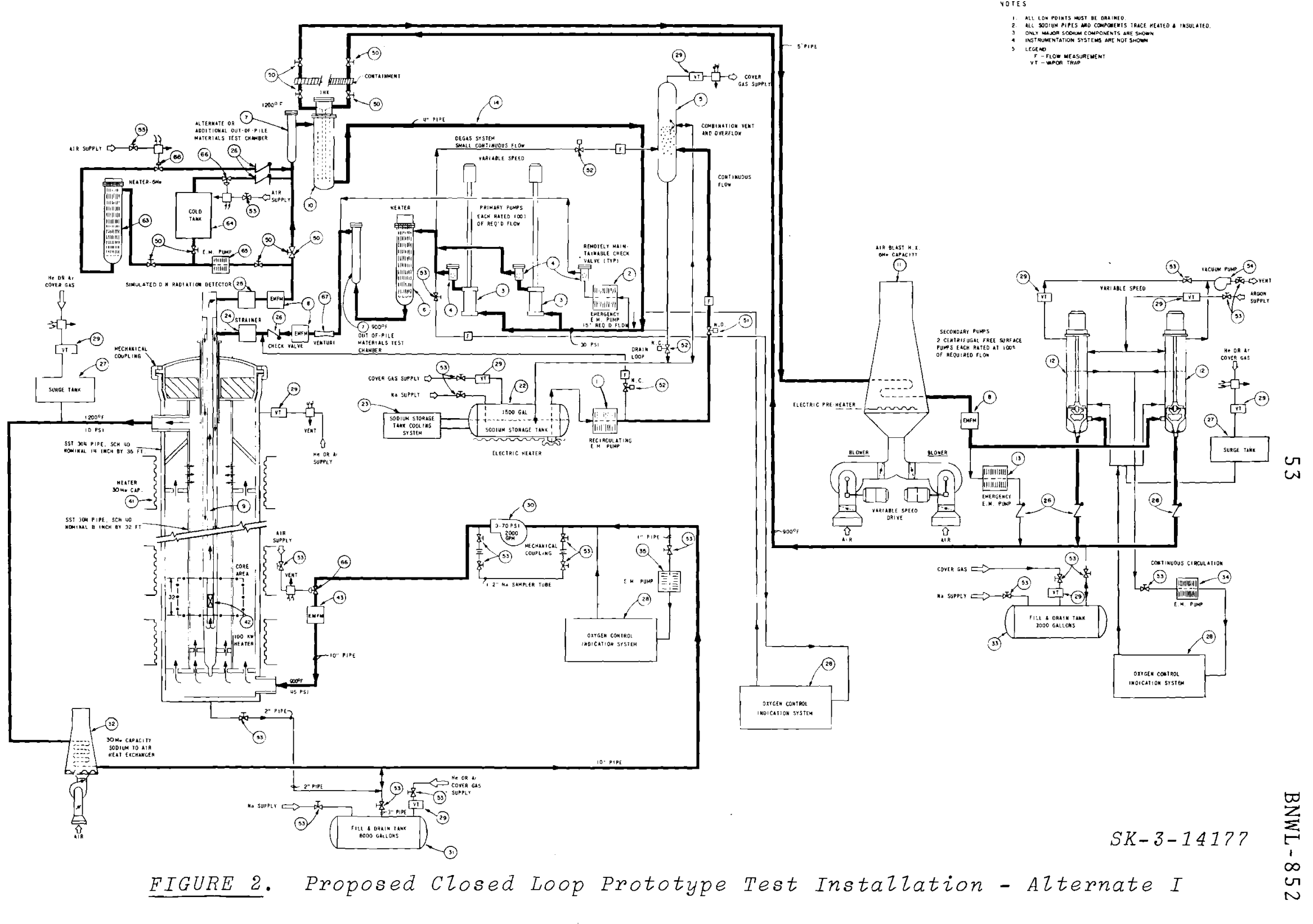


study of reactor flow-induced vibration. The support conditions can vary considerably as the ambient sodium temperatures are varied.

The simulated vessel structure design will provide the capability of subjecting the closed loop in-reactor tube to prototypical parallel and cross flow conditions. (4)

This reactor simulation loop is essential for proper investigation of in-reactor tube thermal stresses, thermal ratcheting and coolant stratification; flow-induced vibrations; mechanical insertion; in-reactor tube and hardware galling, fretting and self-welding; tube and interconnecting piping expansion effects; and compatibility of top face hardware.

The cost estimate includes a new building requiring $6000 \mathrm{ft}^{2}$ of floor space. The building has the capability of accommodating the fuel handling machine. The installation acquisition schedule and possible locations for this and the other five alternate plans are discussed later in the report.

\section{ALTERNATE II}

Alternate II features are shown in Figure 3 (SK-3014178). This alternate consists of a completely prototypical primary system and a secondary system that has all prototypical components, a reactor simulation loop, and sodium purification systems for the three loops.

The prototypical components of the secondary loop will be installed in a piping system simulating the volume, pressure drops, and spatial configuration of the reactor loops. The disadvantages of simulated piping, as opposed to prototypical piping, are mainly in the area of equipment handling and maintenance demonstration.

This alternate has the same closed loop heat capacity capabilities as Alternate I. The reactor simulation loop vill 


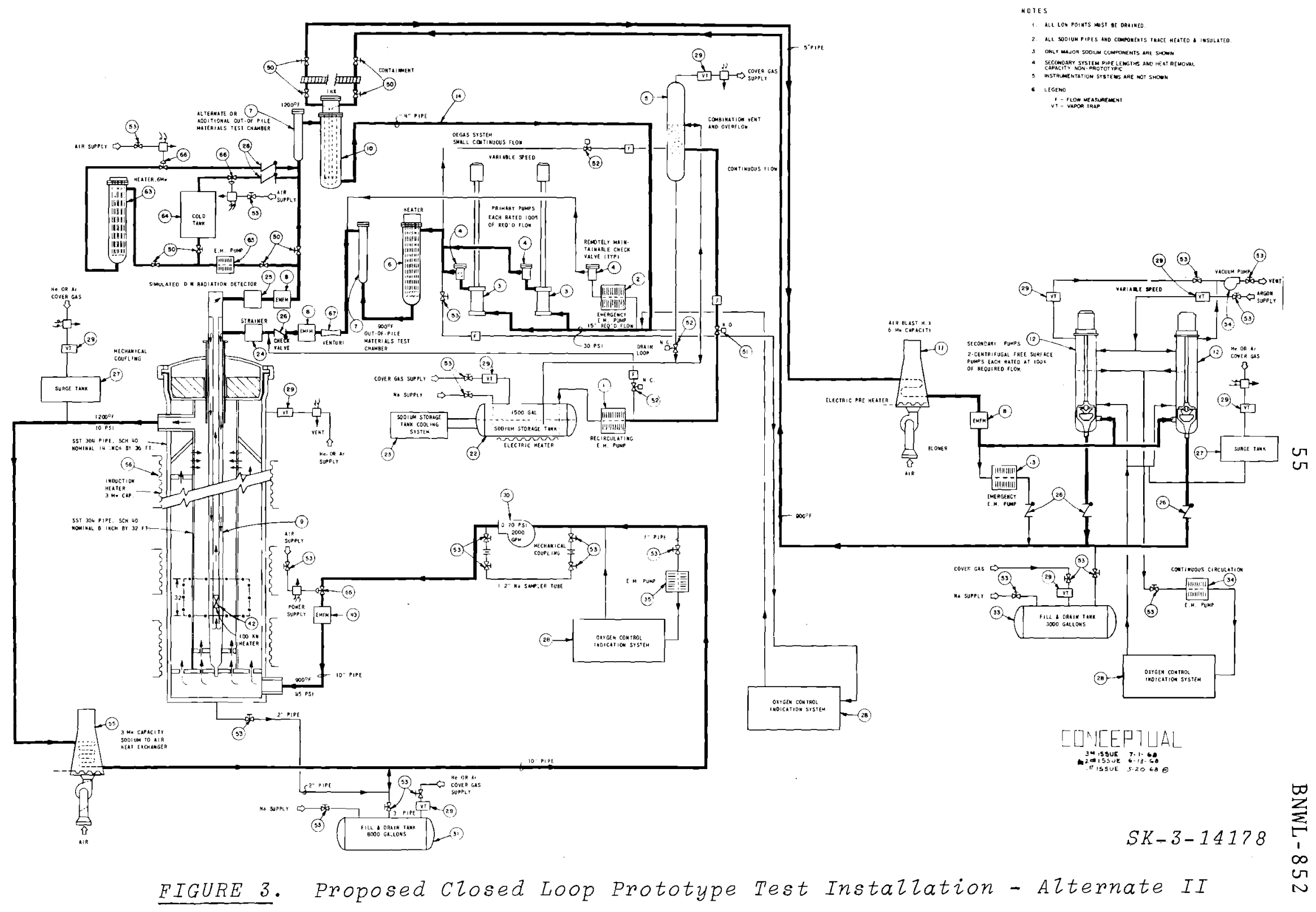


be the same as the Alternate I loop except for heat capacity. This alternative will provide on $1 \mathrm{y}$ a $3 \mathrm{MW}$ capacity. The disadvantages of this reduced heat capacity are reflected in the inability of the loop to simulate reactor flow-induced vibrations at a prototypical vertical temperature distribution, and inability to simulate normal reactor transients.

The cost estimate includes a new building requiring $4800 \mathrm{ft}^{2}$ of floor space. The building has the capability of accommodating the fue 1 handling machine.

ALTERNATE I I I

Alternate III features are shown in Figure 4 (SK-3-14264). This alternative consists of a completely prototypical primary loop, a secondary loop equipped with all prototypical components except for one of the main sodium pumps, a reactor simulation loop, and sodium purification systems for the three loops.

The prototypical components of the secondary loop will be installed in a piping system siumulating the hydraulics of the reactor closed loops. The secondary loop simulation will exclude one of the two main sodium pumps. The absence of the second pump will deprive the system of ability to demonstrate switch-over at a simulated pump failure, as well as the use of a backup pump in case of an actual pump failure.

This alternate has the same closed loop heat capacity as Alternate I. The reactor simulation loop capacity has been reduced to $300 \mathrm{gpm}$ and a 1 in. piping system. The reactor simulation has a heating capacity of $500 \mathrm{~kW}$. Disadvantages of the reduced flow capacity are demonstrated in the inherent inability to generate the mass flow required to simulate prototypical reactor flow-induced vibrations, and inability to simulate reactor temperature transients. 


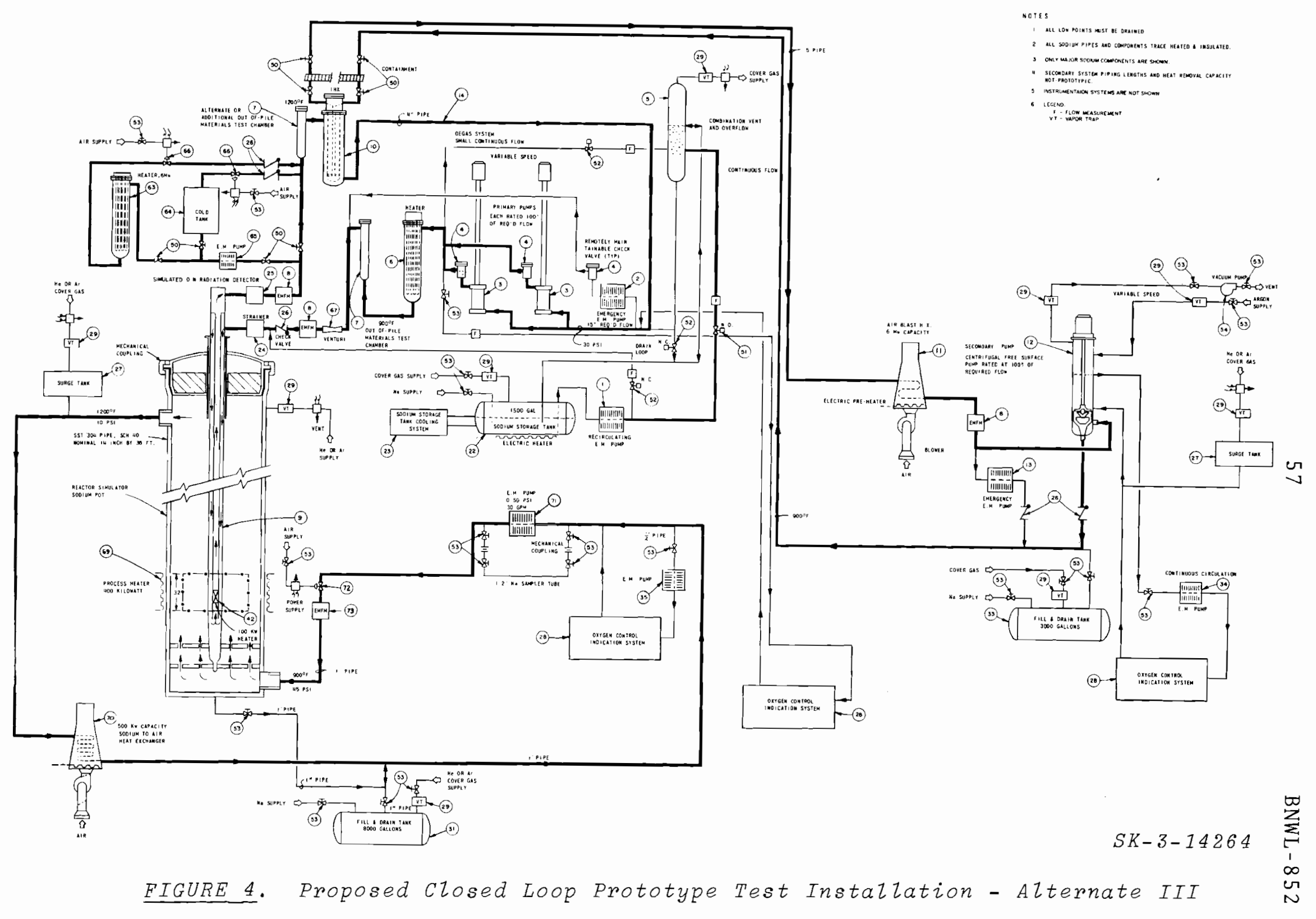


The cost estimate includes a new building requiring $4800 \mathrm{ft}^{2}$ of floor space. The building includes the capability for accommodating the fue 1 handling machine.

ALTERNATE IV

Alternate IV features are shown in Figure 5 (SK-3-14179). This alternate consists of components for a primary and a secondary closed loop, a limited reactor simulation, and sodium purification systems for the two $100 \mathrm{ps}$.

The primary and secondary loop components will be prototypical with the exception of the Intermediate Heat Exchanger (IHX) and Dump Heat Exchanger (DHX). The IHX will simulate only size and hydraulics since a 6 MW heat capacity is not specified for this alternative. The capacity of on $1 \mathrm{y} 1 \mathrm{MW}$ for the DHX will be sufficient to remove the $100 \mathrm{~kW}$ simulated test specimen heat and the pump heats. The reduction in heat capacity will not permit demonstration of the system thermal capabilities. The piping system will be similar to Alternate III.

For Alternate III, the reactor simulation will consist only of an electrodynamic vibrator to simulate the reactor flow-induced vibrations. No sodium loop is provided. The structure supporting the closed loop in-reactor tube will mechanically simulate the tube/reactor interface conditions. The disadvantages of this approach are the nonprototypical reactor temperature profile simulations and the lack of technology that would be required to predict and program a realistic vibration environment.

The cost estimate includes a new building requiring $6200 \mathrm{ft}^{2}$ of floor space. 

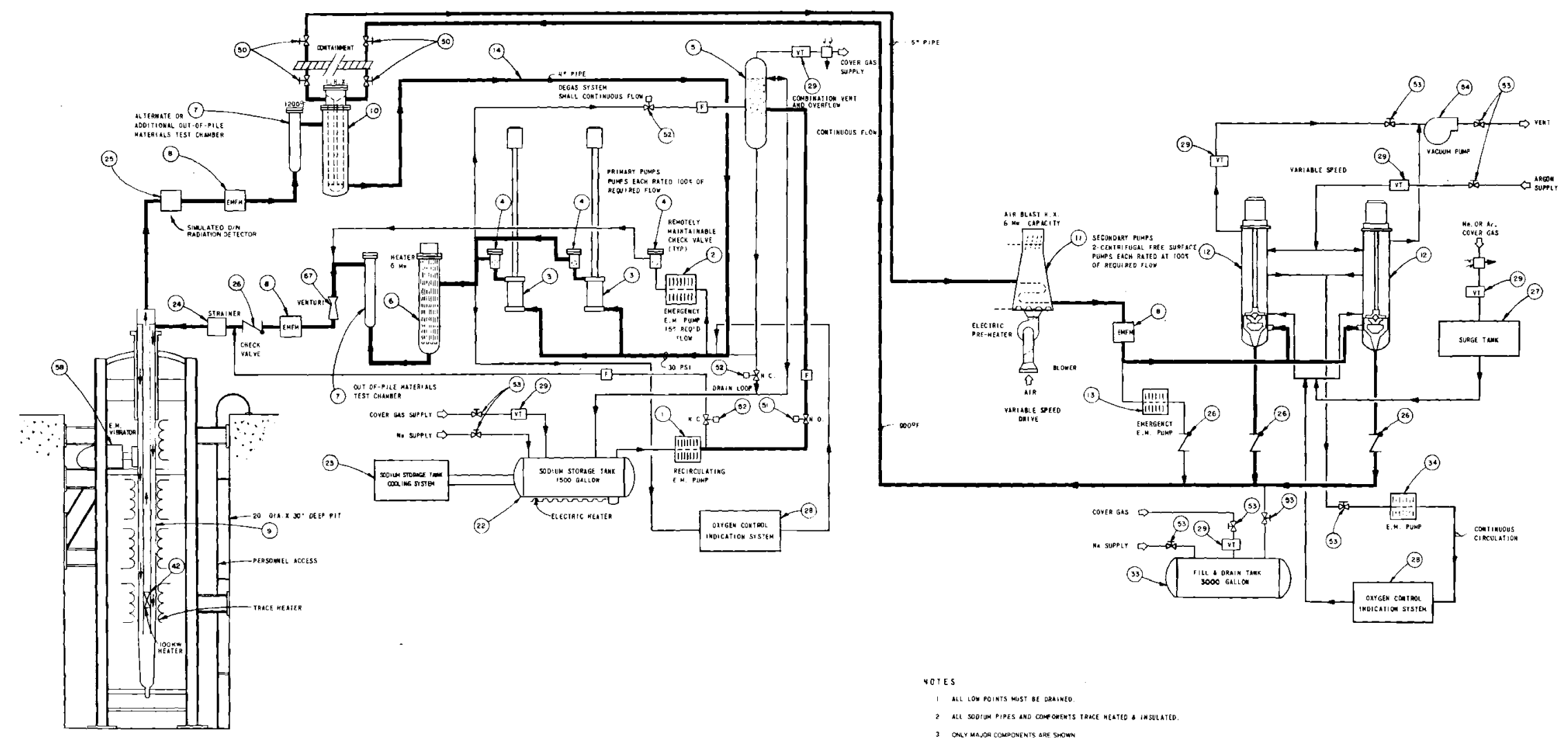

votes

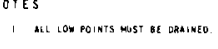

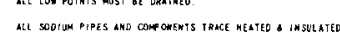

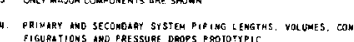

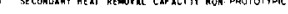

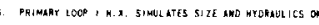

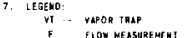

$S K-3-14179$

FIGURE 5. Proposed Closed Loop Prototype Test Installation - Alternate IV 
ALTERNATE V

Alternate $V$ features are shown in Figure 6 (SK-3-14180). This alternate consists of a primary and a secondary closed loop equipped with prototypes of most of the closed loop components, and a sodium purification system for the two 1oops.

In addition to the reduced heat capacity and nonprototypical IHX and DHX of Alternate IV, this alternative would have only one main primary and one main secondary pump. Inability to demonstrate a switch-over at a simulated pump failure and the loss of mechanically-induced vibration sources are the two principal disadvantages.

The reactor simulation will consist only of mechanical fit capabilities. The disadvantage of this approach, as opposed to the reactor simulation provided in Mark IV, is found in the loss of reactor flow-induced vibration simulation.

The cost estimate includes a new building requiring $3200 \mathrm{ft}^{2}$ of floor space.

\section{ALTERNATE VI}

Alternate VI features are shown in Figure 7 (SK-3-14181). This alternate consists of a primary closed loop with a prototype in-reactor tube and a sodium purification system.

The primary closed loop for this alternate consists of a main pump, emergency pump, in-reactor tube, sma11 heat dump, storage tank, and surge tank. This installation will provide the capability for high temperature hydraulic studies. The disadvantages of this alternate, as opposed to Alternate $V$, are the inability to perform remote handling and maintenance on the out-of-reactor loop under prototypical. conditions, and restricted isothermal temperature conditions in the loop.

The cost estimate includes a new building requiring $1200 \mathrm{ft}^{2}$ of floor space. 


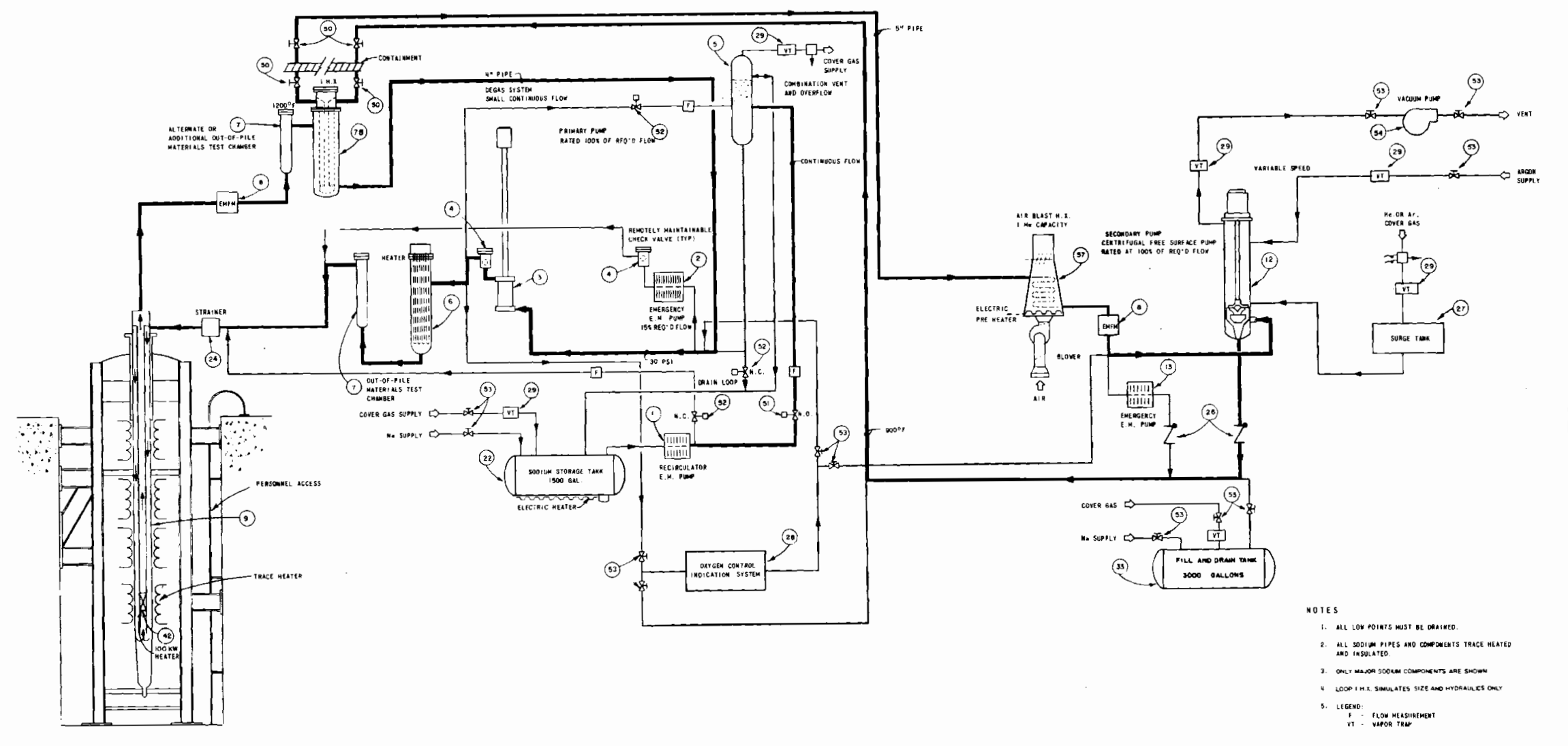

$S K-3-14180$

FIGURE 6. Proposed Closed Loop Prototype Test Instalzation - Alternate V 


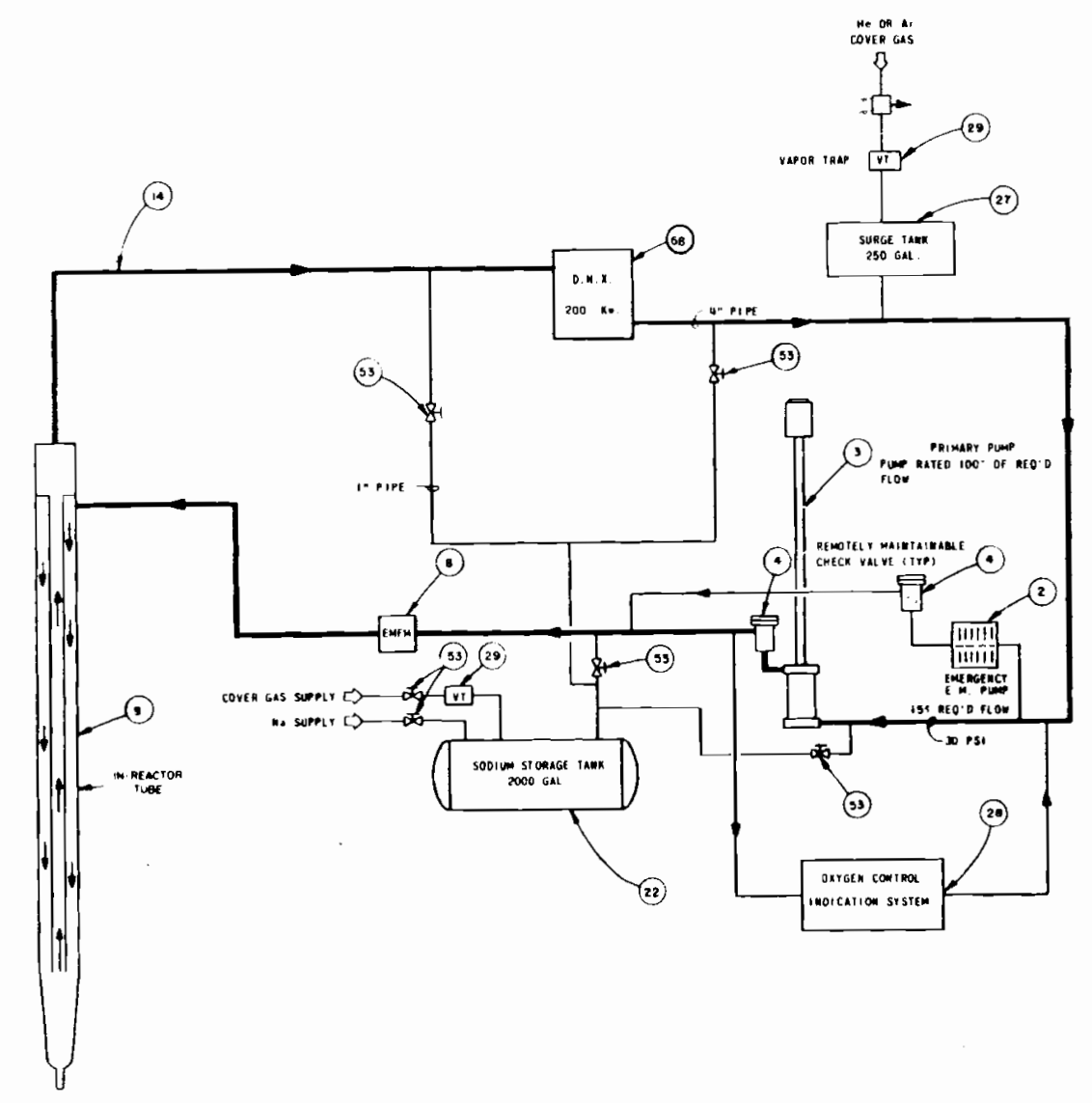

votes

1. Wo witue meaten.

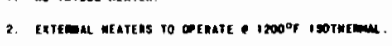

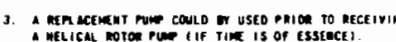

4. Piene

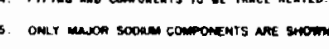

SK-3-14181

FIGURE 7. Proposed Closed Loop Prototype Test Instalzation - Alternate VI 


\section{ALTERNATE SYSTEM TEST LOCATIONS AND SCHEDULES}

\section{LOCATIONS}

Two Richland, Washington locations were considered as candidate installations for housing the closed loop system test. The first installation location was proposed for the 300 Area in the Engineering Building. This building, submitted to the U.S. Atomic Energy Commission as a FY-70 Line Item Project, will include adequate floor space for recommended Alternate III, a sodium storage and purification system, and other support services.

The second location considered was in one of the 190 Buildings, (100 Area). Modification of one of these buildings would provide adequate floor space for the closed loop system test, but would be expensive. The acquisition schedule for this building is consistent with the system test schedule shown in the Closed Loop Management Plan.

\section{SCHE DULES}

Two basic assumptions were made in formulating alternate facility schedules. The first was, that regardless of location, the schedule for acquisition of these facilities would remain the same. The second assumption was that advance design funds would not be made available during the last quarter of FY-69.

Alternate III installation acquisition schedules are shown in Figure 8. As can be seen from these schedules, the building is the limiting item. These schedules could also be applied to Alternates I, II, and IV which essentially require all major closed loop components and comparable floor space. Alternates $V$ and $V I$ require either a smaller number of major components or are not required. In addition, the latter two 


\section{REFEREIICES}

1. M. Shaw. Unpublished Data. Pacific Northwest Laboratory. Richland, Washington, January 28, 1966. (Hemorandum to D. G. WiZZiams: FETF-Program Direction)

2. J.J. Droher. Unpublished Data. Pacific Northwest Laboratory, Richland, Washington, February 16, 1968. (Letter to R. Kolowith: Closed Loop Facilities for Circulation of Sodium, Ref. No.68 LMEC-102)

3. G. Denielou et al. "Main Technical Problems in Construction and Testing of RAPSODIE," ANS-101 Fast Reactors, National Topical Meeting, Apriz 1967 .

4. L. H. Finch, R. E. Peterson, and K. G. Toyoda. Evaluation of FETF Reactor Assembly Development and Testing Program, BNWL-614, Sec. 8.1. Pacific Northwest Laboratory, Richland, Washington, November 1967.

5. E. R. Astrey. Unpublished Data. Pacific Northwest Laboratory, Richland, Washington, July 16, 1968. (Letter to J.M. Shiviey, State of Technology Survey)

6. R. J. Evans and M. K. Mahaffey. Unpublished Data. Pacific lorthwest Laboratory, Richland, Washington, 1966. Preliminary Report: Double Versus single walled Sodium Piping for the FFTF Closed Loop System)

7. R. L. Armstrong et al. "FARET Fuel Assembly Flow Test Loop," presented at ANS 11th Annual Meeting, June 1965.

8. C. B. Jackson et al. Liquid Metals Handbook, Sodium - Nak Supplement, TID-5277. Mine Safety Appliances Co. sponsored by the Atomic Energy Commission and the Department of the Navy, 3 rd ed. June 1955.

9. S. H. Bush. Component Failure Modes and Mechanisms as Applied to Nuclear Power Plants, BNWL-CC-1180, Pacific Northwest Laboratory, Richland, Washington.

10. R. L. Cummings. "Design Problems with Liquid Metal Heat Exchangers," Chem. Eng. Progr., vol. 64, no. 3. 1968.

11. G. M. Hesson, A. Padizla, and J. M. Yatabe. Unpublished Data. Pacific Northwest Laboratory, Richland, Washington, Apriz 6, 1967. (Preliminary Report: Thermal Hydraulics Deveropment)

12. E. R. Astzey. Unpublished Data. Pacific Northwest Laboratory, Richland, Washington, Apriz 6, 1967. (Letter to J.M. Shivley: Closed Loop Management Plan, Ref. Ho. PNL/FFTF 68173) 
$\bullet$ 


\section{DISTRIBUTION}

No. of Copies

AEC Division of Reactor Development and Technology

M. Shaw, Director, RDT

Asst Dir for Nuclear Safety

Analysis \& Evaluation Br, RDT:NS

Environmental \& Sanitary Engrg Br, RDT:NS

Research \& Development Br, RDT:NS

Asst Dir for Plant Engrg, RDT

Applications \& Facilities Br, RDT:PE

Components $\mathrm{Br}$, RDT:PE

Instrumentation \& Control $\mathrm{Br}$, RDT:PE

Liquid Metal Systems Branch, RDT:PE

Asst Dir for Program Analysis, RDT

Asst Dir for Project Mgmt, RDT

Liquid Metals Projects Br, RDT:PM

FFTF Project Manager, RDT:PM

Asst Dir for Reactor Engrg

Control Mechanisms $\mathrm{Br}$, RDT: RE

Core Design $\mathrm{Br}$, RDT:RE

Fuel Fabrication $\mathrm{Br}$, RDT:RE

Fue 1 Hand 1 ing $\mathrm{Br}$, RDT:RE

Reactor Vessels $\mathrm{Br}, \mathrm{RDT}: \mathrm{RE}$

Asst Dir for Reactor Tech

Coolant Chemistry (RDT)

Fue1 Recycle Branch (RDT)

Fuels \& Materials Br, RDT:RT

Reactor Physics Br, RDT:RT

Special Technology $\mathrm{Br}$, RDT:RT

Asst Dir for Engrg Standards

AEC Chicago Patent Group

G. H. Lee, Chief

R. K. Sharp (Richland)

AEC Idaho Operations office

Nuclear Technology Division

C. W. Bills, Director

AEC Richland Operations Office

FFTF Program

J. M. Shivley

AEC San Francisco Operations Office

Director, Reactor Division 
No. of

Copies

4

AEC Site Representatives - PNL

P. G. Holsted

L. R. Lucas

A. D. Toth

4

AEC Site Representatives

Argonne National Laboratory

Atomics International

Atomic Power Development Assoc.

General Electric Co.

2

Argonne National Laboratory

R. A. Jaross

LMFBR Program Office

6

Atomics International

D. J, Cockeram

Liquid Metal Engrg Center

R. W. Dickinson

1

Atomic Power Development Assoc.

Document Librarian

2 Babcock \& Wilcox Co.

Atomic Energy Division

S. H. Esleeck

Boiler Division

T. P. Farrell

2

Bechte1 Corporation

J. J. Teachnor

Project Administrator, FFTF

1 Combustion Engineering

1000 MWe Follow-On Study

W. P. Staker, Project Manager

2 Gulf General Atomic Inc.

General Atomic Div.

D. Coburn 
No. of

Copies

5

General Electric Co.

Advanced Products Operation

Karl Cohen

Bertram Wolfe

Nuclear Systems Programs

D. H. Ahmann

1

Idaho Nuclear Corporation

D. R. deBoisblanc

1

$\underline{\text { PNL Representative }}$

N. A. Hill (ZPR III)

1

Stanford University

Nuclear Division

Division of Mechanical Engrg

R. Sher

5

Westinghouse Electric Corp.

Atomic Power Division

Advanced Reactor Systems

J. C. R. Ke11y

111

Battelle-Northwest
S. 0. Arneson
E. R. Astley
R. Aungst
W. Babcock
R. G. Baumgarte1
R. A. Bennett
J. O. Berg
L. J. Bese 1
C. L. Boyd
D. C. Boyd
W. A. Burns 
Battelle-Northwest (contd)

C. M. Cantre11

J. R. Carre11

W. E. Cawley

W. S. Chenault

P. D. Cohn

D. L. Condotta

R. R. Cone

K. O. Creek

J. M. Davidson

E. M. Davis

L. J . Defferding

V. A. DeLiso

R, R. Derusseau

L. M. Finch

E. E, Garrett

S. M, Gill

R. F. Gilmore

J.W. Hagan

K. M. Harmon

R. A. Harvey

B. R. Hayward

R. E. Heineman

C. H. Henager

$\mathrm{R}$. J. Hennig

P. L: Hofmann

M. 'I'. Jakub

B. M. Johnson

H. G. Johnson

E. M. Johnston

$\mathrm{J}$. H. Kinginger

W, E, Kinse 1

R, L, Knecht

R. Kolowith

J. W. Kolb

C. D, Leach

C. W. Lindenmeier

C. E. Love

M. K. Mahaffey

W. B. McDona1d

R. A. Moen

C. A. Munro

C. R. Nash

J. C. Noakes 
Battelle-Northwest (contd)

C. L. Peckinpaugh

R. E. Peterson

0 . W. Priebe

H. L. Pringle

W. E. Roake

R. L. Roske

G. R. Sawte11e

E. B. Schwenk

F. H. Shade 1

D. W. Shannon

D. E. Simpson

C. R. F. Smith

R. J. Squires

D. D. Stepnewski

G. H. Strong

C. D. Swanson

P. K. Telford

J. C. Tobin

K. G. Toyoda

M. A. Voge 1

R. C. Walker

P. C. Walkup

G. R. Waymire

J. H. Westsik

J. F. Wett

L. A. Whinery

T. W. Withers

N. G. Wittenbrock

M. R. Wood

F. W. Woodfield

R. R. Wyer

J. M. Yatabe

F. D. Zupan

FFTF Files

Legal (2)

Technical Publications

Technical Information 
. . 